NBER WORKING PAPER SERIES

\title{
CAPITAL INVESTMENTS AND STOCK RETURNS
}

\author{
Sheridan Titman \\ K.C. John Wei \\ Feixue Xie \\ Working Paper 9951 \\ http://www.nber.org/papers/w9951
}

\author{
NATIONAL BUREAU OF ECONOMIC RESEARCH \\ 1050 Massachusetts Avenue \\ Cambridge, MA 02138 \\ September 2003
}

The authors appreciate the helpful comments of the seminar participants at Peking University, the Hong Kong University of Science and Technology, National Central University, National Chengchi University, University of Arizona, and the Ninth SFM Conference held in Kaoshiung, Taiwan. The authors also thank Andres Almazan, Paul Malatesta (the editor), and two anonymous referees for insightful comments and Dr. Virginia Unkefer for editorial assistance. Sheridan Titman and John Wei acknowledge the financial support from an RGC Competitive Earmarked Research Grant of the Hong Kong Special Administration Region, China (HKUST6014/99H). The views expressed herein are those of the authors and not necessarily those of the National Bureau of Economic Research.

(C)2003 by Sheridan Titman, K.C. John Wei, and Feixue Xie. All rights reserved. Short sections of text, not to exceed two paragraphs, may be quoted without explicit permission provided that full credit, including (C) notice, is given to the source. 
Capital Investments and Stock Returns

Sheridan Titman, K.C. John Wei, and Feixue Xie

NBER Working Paper No. 9951

September 2003

JEL No. G1, G3

\section{$\underline{\text { ABSTRACT }}$}

Firms that substantially increase capital investments subsequently achieve negative benchmarkadjusted returns. The negative abnormal capital investment/return relation is shown to be stronger for firms that have greater investment discretion, i.e., firms with higher cash flows and lower debt ratios, and is shown to be significant only in time periods when hostile takeovers were less prevalent. These observations are consistent with the hypothesis that investors tend to underreact to the empire building implications of increased investment expenditures. Although firms that increase capital investments tend to have high past returns and often issue equity, the negative abnormal capital investment/return relation is independent of the previously documented long-term return reversal and secondary equity issue anomalies.

Sheridan Titman

Department of Finance University of Texas at Austin

Austin, TX 78712-1179

and NBER

titman@mail.utexas.edu

K.C. John Wei

Department of Finance

Hong Kong University of Science and Technology

Clearwater Bay, Kowloon, Hong Kong

johnwei@ust.hk

Feixue Xie

Department of Economics and Finance

Southern Connecticut State University

New Haven, CT 06515

xief1@southernct.edu 


\section{Capital Investments and Stock Returns}

\section{Introduction}

There is now a substantial literature that examines corporate capital expenditures. For example, although firms tend to invest more following increases in their stock prices, cash flows tend to be the best predictor of a firm's investment expenditures (see, for example, Fazzari, Hubbard and Peterson (1988) and Morck, Shleifer and Vishny (1990)). ${ }^{1}$ It is also the case that stock prices tend to respond favorably to announcements of major capital investment. ${ }^{2}$ However, financing choices that are associated with increased investment, such as equity issuances, generally result in negative stock returns (see for example, Loughran and Ritter (1995) and others), while those choices associated with decreased investment, such as repurchases, generally result in positive returns (see, for example, Ikenberry, Lakonishok, and Vermaelen (1995) and others).

There are a number of reasons why increased investment expenditures should be viewed favorably. First, higher investment expenditures are likely to be associated with greater investment opportunities. Second, higher investment expenditures may also indicate that the capital markets, which provide financing for the investments, have greater confidence in the firm and its management. The above-cited event studies provide evidence that is consistent with these views, and our own evidence also indicates that stock prices do quite well in those years in which capital expenditures increase. However, it is difficult to interpret either the event studies or the evidence of higher stock returns in years in which firms increase capital expenditures. First, there is likely to be a tendency for firms to publicly announce only those investment

\footnotetext{
${ }^{1}$ See Hubbard (1998) for an excellent review of this literature.

${ }^{2}$ McConnell and Muscarella (1985) indicate that announcements of increases in planned capital investments are generally associated with significantly positive excess stock returns. In follow-up studies, Blose and Shieh (1997)
} 
expenditures that are likely to be viewed favorably. Second, higher stock prices may make it easier for firms to increase investment expenditures, so that higher stock prices in years where investment expenditures are higher need not indicate that the market views the investment expenditures favorably.

There are also reasons why increased investment expenditures may result in negative stock returns. For example, managers have an incentive to put the best possible spin on both their new opportunities as well their overall business when their investment expenditures are especially high because of their need to raise capital as well as to justify their expenditures. If investors fail to appreciate managements' incentive to oversell their firms in these situations, stock returns subsequent to an increase in investment expenditures are likely to be negative. This effect is likely to be especially important for managers who are "empire builders," and invest for their own benefits rather than the benefits of the firm's shareholders (see Jensen (1986)).

The evidence provided in this paper is consistent with the idea that investors tend to underreact to the empire building implications of increased investment expenditures. Specifically, we find that firms that increase their investment expenditures the most tend to underperform their benchmarks over the following five years. A significant amount of this abnormal performance occurs around earnings announcements, providing additional evidence that our findings are generated because investors incorrectly assess the empire building tendencies of managers rather than because of benchmark errors. Moreover, this negative relation between increased capital expenditures and subsequent returns tends to be stronger for firms with greater investment discretion, i.e., firms with less debt or more cash flows. In

and Vogt (1997) find a significant positive relation between the magnitude of the stock market reaction to capital investment announcements and the level of new investment. 
addition, the relation between returns and abnormal capital expenditures fails to exist in the 1984 to 1989 period in which the empire-builders were subject to hostile takeovers.

Our evidence is potentially related to the DeBondt and Thaler (1985) return reversal evidence as well as to the Loughran and Ritter (1995) evidence that equity issuers tend to exhibit negative long-run returns. As we mentioned at the outset, firms that increase investment expenditures are likely to have enjoyed positive stock returns and are also more likely to have issued equity in the past. Hence, the previously documented anomalies may be generating the negative abnormal capital expenditure/return relation that we document. However, we find that

this is not the case. Indeed, we find the negative abnormal capital expenditure/return relation is independent of the long-term return reversal and secondary equity issue anomalies.

The remainder of the paper is organized as follows. Section II briefly discusses the experimental design of the tests and data requirements and Section III outlines the methodology. The findings on the relationship between abnormal capital investments and expected returns are presented in Section IV. Section V examines the agency cost explanation for the negative abnormal investment/return relation. In particular, we examine whether the negative relation between abnormal capital investments and subsequent stock returns behave differently between firms with investment discretion and those without discretion. Section VI reports the robustness tests on the relation and finally, Section VII concludes the paper.

\section{Experimental Design and Data Description}

To test the relation between abnormal capital investments and subsequent stock returns we examine the returns on portfolios formed on the basis of abnormal levels of capital investment. More specifically, we test whether returns on portfolios with low abnormal capital investments 
are significantly higher than those with high abnormal capital investments. Once the negative relation between abnormal capital investments and subsequent stock returns is established, we investigate possible explanations for this negative relation by separating firms into two groups based on their investment discretion as measured by cash flows or leverage. We then examine whether the magnitude of the negative relation between abnormal capital investment and subsequent stock returns is substantially different between these two groups of firms.

To carry out these tests, we consider all domestic, primary stocks listed on the New York Stock Exchange (NYSE), American Stock Exchange (Amex), and Nasdaq stock markets. Following Fama and French (1992, 1993), we exclude closed-end funds, trusts, ADRs, REITs, units of beneficial interest, and other financial institutions. The monthly data on stock returns, stock prices, and number of shares outstanding are obtained from the Center for Research in Security Prices (CRSP). The U.S. one-month Treasury bill rates are used as risk-free rates. Financial statement data, such as book equity, cash flows, long-term debt, and sales are obtained from the COMPUSTAT tapes. While the sample period for financial data covers from 1969 to 1995, the test period or the sample period for stock returns covers from July 1973 to June 1996.

To be included in the tests, a firm must meet the following criteria. First, it should have the CRSP stock prices for December of year $t$-1 and June of year $t$ and the COMPUSTAT book equity for year $t-1$. Second, its annual total net sales should be no less than US\$10 million to exclude firms at their early stage of development. Third, it should not have negative book equity for the fiscal year ending in calendar year $t$-1. Moreover, following Fama and French (1992, 1993), firms are not included until they have appeared in COMPUSTAT for two years to avoid the potential survival/selection bias inherent in the way COMPUSTAT adds firms to its tapes (Banz and Breen (1986)). 
A firm's market equity $(M E)$ is defined as its price multiplied by the number of shares outstanding, and its market size (SZ) is measured as the $M E$ at the end of June of year $t$. The book-to-market equity ratio $(B M)$ is computed as the ratio of the book equity $(B E)$ of a firm for the fiscal year ending in calendar year $t-1$ to the firm's $M E$ at the end of December of $t-1$. As in Fama and French (1993), we define book equity as the COMPUSTAT book value of stockholders' equity, plus balance sheet deferred taxes and investment tax credits (if available), minus the book value of the preferred stock. Depending on availability, the redemption, liquidation, or par value (in that order) is used to estimate the value of the preferred stock.

In the results reported in this paper, the measure of abnormal capital investment $\left(C I_{t-1}\right)$ in the formation year $t$, is calculated as follows:

$$
C I_{t-1}=\frac{C E_{t-1}}{\left(C E_{t-2}+C E_{t-3}+C E_{t-4}\right) / 3}-1,
$$

where $C E_{t-1}$ is a firm's capital expenditures (COMPUSTAT data item 128) scaled by its sales in year $t-1$. We use the last three-year average capital expenditures to project the firm's formation year's benchmark investment, and interpret firms with high $C I$ as high investors. The formation year $t$ is the year when the year $\mathrm{t}-1 C I$ is measured and the $C I$ portfolios are formed (i.e, the returns from July of year $t$ to June of year $t+1$ are matched against with $\left.C I_{t-1}\right)$. Using sales as the deflator, we implicitly assume that the benchmark level of capital expenditures will grow proportionately with sales. By this definition, a $C I$ value equal to (greater than, less than) zero indicates that the formation year's capital investment is the same as (greater than, less than) the prior three years' average. Our definition of $C I$ can actually be viewed as a measure of abnormal investment. To see how the results are sensitive to the measure of $C I$, we also use $C E_{t-1}-\left(C E_{t-2}\right.$ $\left.+C E_{t-3}+C E_{t-4}\right) / 3, C E_{t-1}$ alone, replacing the last three-year average with the last five-year 
average capital expenditures in equation (1), and the $C I$ measure without deflating to measure $C I_{t-1}$. In addition, we also use total assets to replace sales as the deflator in all $C I$ measures. The results (not reported here) are basically insensitive to alternative measures of $C I$.

To ensure that accounting information is known before we use it to explain the stock returns, following Fama and French (1992), we match stock returns for the period between July of year $t$ to June of year $t+1$ (which is referred to as the test period or the year 1 returns after formation year $t$ ) to the accounting data (including $C I$ ) of a firm for the fiscal year ending in calendar year $t-1$. Firms with one or more missing monthly returns are excluded from the sample for that particular year. Our initial sample includes 58,880 industrial firm-years (an average of 2,560 firms a year) that are available in CRSP and COMPUSTAT for at least 2 years. The sample is reduced to an average of 1,902 firms a year, since we require a firm to have at least four years of data to first compute its abnormal capital investment and then to match with the subsequent stock returns. The sample size is further reduced to an average of 1,725 firms a year, when we exclude firms with missing stock returns in the testing period. Finally, by excluding firms that do not meet data requirements on sales and book equity, we obtain a final sample that has an average of 1,635 firms a year.

\section{Methodology}

We use three different approaches for evaluating the returns of the various investment strategies that we consider. The first approach measures excess returns relative to benchmarks that are constructed to have very similar firm characteristics (i.e., size, book to market, and momentum) as the evaluated portfolio. The second approach applies Carhart's (1997) adaptation of the Fama and French (1993) method of calculating excess returns. And finally, we follow 
Chopra, Lakonishok, and Ritter (1992) to examine returns around a short window surrounding the firms' earnings announcement dates.

\section{A. Characteristic-based Benchmark Portfolios}

Firms with different levels of investment expenditures are likely to be subject to different types of risk. One might expect that firms that invest the most are the riskiest, since a greater fraction of their value consists of growth options. Alternatively, since the least risky firms have the lowest cost of capital, they may invest the most. In any event, when one compares the returns of firms that invest high and low amounts, it is critical that appropriate benchmarks are chosen. Here we will be controlling for firm characteristics as well as factor sensitivities.

Our procedure for calculating benchmark-adjusted returns follows the methodology outlined in the Daniel, Grinblatt, Titman, and Wermers (1997) study that developed benchmarks to evaluate mutual fund performance. Specifically, we form 125 benchmark portfolios that capture three stock characteristics namely book-to-market equity, size, and momentum, which are significantly related to the cross-sectional variation in returns. ${ }^{3}$ These benchmark portfolios are formed as follows. First, starting with July of year $t$, the universe of common stocks is sorted into five portfolios based on each firm's size (SZ) at the end of June of year $t$ according to the breakpoints for the NYSE firms. The breakpoints for size are obtained by sorting NYSE firms into quintiles based on their $S Z$ measures at the end June of year $t$ in ascending order. The size of each firm in our sample is then compared with the breakpoints to decide which portfolio the firm belongs to. Firms in each $S Z$ portfolio are further equally sorted into quintiles based on their book-to-market ratio $(B M)$ at the end of year $t$-1. Finally, the firms in each of the $25 S Z / B M$ 
portfolios are equally sorted into quintiles based on their prior-year return $(P R 1 Y R$, calculated through the end of May of year $t$ to reduce the bias from bid-ask bounces and monthly return reversals). The interception of the five $S Z$, the five $B M$, and the five $P R I Y R$ classifications results in a total of 125 benchmark portfolios. The value-weighted monthly returns on benchmark portfolios are calculated from July of year $t$ to June of year $t+1$. All benchmark portfolios are rebalanced each year.

Once we form these 125 characteristic-based benchmark portfolios, calculating the excess return is straightforward. Each stock, in each year, is assigned to a benchmark portfolio according to its rank based on $S Z, B M$, and $P R I Y R$. Excess monthly returns of a particular stock are then calculated by subtracting the stock's corresponding benchmark portfolio's returns from the stock's returns. Specifically, the characteristics-adjusted return is defined as:

$$
R_{i t}^{C H} \equiv R_{i t}-R_{t}^{C H_{i}}
$$

where $R_{i t}$ and $R_{t}^{C H_{i}}$ are the return on security $i$ and the return on a SZ-BM-PRIYR matched portfolio in month $t$, respectively. The excess returns on individual stocks are then used to calculate the value-weighted excess monthly returns on test portfolios that are formed based on the sortings of $C I$ and other variables. The excess returns on test portfolios are sometimes referred to as benchmark-adjusted portfolio returns.

\section{B. The Carhart Four-Factor Model}

To control for factor risk, the value-weighted excess returns on test portfolios are regressed on the Fama-French three factors and the Carhart momentum factor:

\footnotetext{
${ }^{3}$ See Fama and French (1992, 1993), Jegadeesh and Titman (1993, 2001), Daniel and Titman (1997), and Daniel, Titman, and Wei (2001).
} 


$$
A R_{p, t}=\alpha_{p}+\beta_{H M L, p} R_{H M L, t}+\beta_{S M B, p} R_{S M B, t}+\beta_{M k t, p}\left(R_{M k t, t}-R_{f t}\right)+\beta_{\mathrm{Pr} 1 y r, p} R_{\mathrm{Pr} 1 y r, t}+\varepsilon_{p, t} .
$$

In equation (3), $A R_{p, t}$ is the benchmark-adjusted return on $C I$ ranked portfolio $p$; $R_{f t}$ is the riskfree rate; $R_{H M L, t}, R_{S M B, t}$, and $R_{M k, t}$ are the three factors suggested by Fama and French (1993, 1996); and $R_{P r l y r, t}$ is the momentum factor. More specifically, $R_{H M L}$ is the book-to-market factor and is the difference between the return on a portfolio of high (the top 30\%) book-to-market stocks and the return on a portfolio of low (the bottom 30\%) book-to-market stocks (HML, High Minus $L o w) . R_{S M B}$ is the size factor and is the difference between the return on a portfolio of small (the bottom 50\%) stocks and the return on a portfolio of large (the top 50\%) stocks ( $S M B$, Small Minus $B$ ig). $R_{M k t}$ is the market factor and is the return on the market portfolio. $R_{P r l y r, t}$ is the difference between the return on a portfolio of stocks with high (the top 50\%) prior-year returns and the return on a portfolio of stocks with low (the bottom 50\%) prior-year returns (PRIYR, high minus low prior-year return, skipping the return in the formation month). The momentum factor suggested by Carhart (1997) captures the Jegadeesh and Titman (1993, 2001) one-year momentum in stock returns. The estimated intercept from this regression captures the riskadjusted returns on our $C I$-sorted portfolios. We refer to this model as the Carhart four-factor model.

\section{Excess Returns Surrounding Earnings Announcements}

Although our tests adjust returns with a characteristic-benchmark as well as with a factor model, it is still plausible that the abnormal returns we observe reflect risk factors that are not accounted for by our benchmarks. To address this possibility, we provide an additional test in this section that is based on stock returns of past high and low $C I$ firms around earnings 
announcement dates. If significant excess returns are generated because of benchmark errors, we expect them to accrue relatively smoothly over the year, since systematic risk is not likely to change a lot from day to day. However, if investors fail to appreciate the negative effects of overinvestment, they are likely to be unpleasantly surprised when the firms announce their earnings, implying that a significant portion of the abnormal performance for low $C I$ firms over high $C I$ firms will occur around the earnings announcements. ${ }^{4}$ This methodology, which was initially proposed by Chopra, Lakonishok, and Ritter (1992) to study overreaction, has been applied in several studies to test for the possibility that investors have biased expectations. For example, Jegadeesh and Titman (1993) apply this approach to investigate the determinants of momentum profits and La Porta, Lakonishok, Shleifer, and Vishny (1997) apply this approach to examine the value/growth premium.

\section{Empirical Results}

A. Distributional Characteristics of Returns on Portfolios Formed on Capital Investments

We first form five capital investment $(C I)$ portfolios and then examine the relation between abnormal capital expenditures and subsequent stock returns on the $C I$ portfolios. Starting with July of year $t$, we sort all stocks into quintiles based on their year $t-1$ capital investment measures in ascending order. The firms remain in these portfolios from July of year $t$ to June of year $t+1$. Based on these portfolios, we form a $C I$-spread portfolio that has a one-dollar long position in the two lowest $C I$ portfolios (the $1^{\text {st }}$ and the $2^{\text {nd }}$ ) and a one-dollar short position in the two highest $C I$ portfolios (the $4^{\text {th }}$ and $5^{\text {th }}$ ). The portfolios are rebalanced each year.

\footnotetext{
${ }^{4}$ An alternative approach for determining whether investors have biased expectations is to look at changes in analyst earnings estimates (see, for example, Teoh and Wong (2002) and others). Specifically, one could examine whether there are biases in earnings estimates that are systematically related to capital investment expenditures.
} 
The distributional characteristics of the benchmark-adjusted returns on the $C I$ portfolios are reported in Panel A of Table 1. It is revealed that except for the lowest CI quintile, the benchmark-adjusted mean return decreases monotonically with abnormal capital investments. A further inspection shows that firms with high abnormal investments are penalized with negative benchmark-adjusted returns, while firms with low abnormal investments are rewarded with positive benchmark-adjusted returns in more than half of the time during the sample period. The statistics on the $C I$-spread portfolio shows that the mean excess return $(0.168 \%$ per month) is above the median $(0.119 \%$ per month) and is significantly different from zero with a $p$-value of less than 0.01. The statistics in Panel A of Table 1 indicate that the better performance of low investors over high investors is not due to outliers.

[Put Table 1 here]

\section{B. The Year-to-Year Performance of the CI-Spread Strategy}

To examine the riskiness of the $C I$-spread strategy and the persistence of the negative relation between abnormal capital investments and stock returns, we examine the year-to-year returns of the strategy. Panel B of Table 1 presents the year-to-year performance (from July 1973 to June 1996) of the zero-cost benchmark-adjusted $C I$-spread portfolio. It reports the performance of the $C I$-spread portfolio in the first through the fifth year following the formation year as well as the five-year cumulative returns. The performance is measured by annual returns, which are computed by compounding the twelve monthly returns from July of year $t$ to June of year $t+1$.

The results presented in the last row of Panel B in Table 1 suggest that the stock returns of firms that invest the least tend to outperform the stock returns of firms that invest the most for at

While this would also be a good approach, data on analyst forecasts are not available for the early part of our 
least 5 years. The returns in year $2(2.26 \%)$, year $3(1.91 \%)$, year $4(1.85 \%)$, and year $5(1.64 \%)$ are all statistically indistinguishable from the year 1 returns and are all reliably different than zero. However, the average return on $C I$-spread in year 6 after portfolio formation (not reported in the Table) is $1.05 \%$ and is statistically insignificant. A close look at the year-to-year return on the $C I$-spread strategy reveals that low abnormal investment stocks outperform high abnormal investment stocks in about two-thirds of the years (column 2 of Panel B in Table 1); the year-toyear returns are strongly positive in each year between 1974 and 1980, they are negative in 1981 and each year between 1984-1989, and are positive again in all subsequent years. This return pattern is very unlikely to occur purely by chance, which is supported by a formal t-test on the null hypothesis that the chances of having a positive or a negative annual return on $C I$-spread are 50-50. Specifically, the $C I$-spreads are positive in 15 out of 17 years during the sample period that excludes the hostile takeover years from 1984-1990 (to be discussed below). The test statistic on the null hypothesis is 4.75 for this sample period and strongly rejects the null at the 0.005 significance level. For years between 1984 and 1989, all CI-spreads are negative, which again strongly reject the null hypothesis that the chance is $50-50$ in any given year.

The observed time-series return pattern coincides, however, with the wave of the hostile takeover and merge activity, and is consistent with our empire builder explanation. In a paper that discusses the rise and fall of hostile takeovers since the 1980s, Holmstrom and Kaplan (2001) finds that the number of leverage buyouts (LBOs) and hostile takeovers increased substantially in the 1984 to1990 period. Our evidence suggests that the $C I$-spread returns were very high in the 70s when lax corporate governance and a weak takeover market allowed firms to overinvest. However, after 1984, many of the firms with a tendency to overinvest were

sample and there are no data on earnings estimates for most of the smaller firms in our sample. 
subject to either hostile takeovers, or were forced to make value-improving changes to preempt these takeovers. In either case, the empire builders would be expected to exhibit positive abnormal returns in this subperiod. However, because of various impediments to takeovers introduced in the late 1980s, the relation between abnormal investments and returns may have again reversed in the later period. We therefore define the hostile takeover period as from 1984 to 1989 that corresponds with the monthly return period from July of 1984 to June of 1990 .

C. The Relation between Capital Investments and Stock Returns

The statistical tests of the benchmark-adjusted returns on the $C I$ portfolios are presented in Table 2. Since empire builders were subject to hostile takeovers in the 1984 to 1989 period as evidenced in Panel B of Table 1, in addition to reporting results in all years, we also report results in non-hostile takeover years and in hostile takeover years separately. The results for benchmark-adjusted returns from all years (Column 2) demonstrate that one of the two low investors is statistically significantly positive at the five percent level, while both of the two high investors are significantly negative at the five percent level. In addition, the mean returns differ reliably from each other across the five $C I$ portfolios as evidenced by the Wilks' Lambda statistics $(F$-value $=2.08$ with a $p$-value of 0.026$)$. Furthermore, the mean return on the $C I$ spread portfolio is significantly positive with a value of $0.168 \%(t$-value $=2.91)$ per month or $2.02 \%(12 \times 0.168 \%)$ per year, indicating that firms that invest more realize lower stock returns than firms that invest less after controlling for size, book-to-market equity, and momentum effects. A further inspection on the mean excess returns indicates that the underperformance from high investors and the outperformance from low investors are not symmetric. High investors underperform the characteristic benchmarks by $0.105 \%(=(0.083+0.127) / 2)$ per month, 
while low investors outperform the characteristic benchmarks by only $0.062 \%(=(0.042+$ $0.083) / 2$ ) per month.

[Put Table 2 here]

Although our benchmarks control for return differences that arise because of differences in firm characteristics, the benchmarks do not necessarily control for factor risk. In order to control for factor risk, we regress benchmark-adjusted $C I$ portfolio returns on the Carhart four factors. The results reported in Column 3 of Table 2 show that three out of five estimated intercepts are reliably different from zero and all of the five estimated intercepts are significantly different from each other across the five $C I$ portfolios $(F$-value of Wilks' Lambda $=4.68$ with a $p$-value of 0.001). With the exception of the first quintile, the risk-adjusted returns monotonically decrease with abnormal capital investments. In addition, the estimated intercept for the zero-cost $C I$ spread portfolio is significantly positive, indicating that the low return for high investors is not due to risks associated with the Carhart four factors. After adjusting for stock characteristics and taking into account the Carhart four factors, low $C I$ firms still earn, on average, a return of about $0.192 \%(\mathrm{t}$-value $=3.25)$ per month or $2.3 \%$ per year more than do high $C I$ firms. In other words, the Daniel, Grinblatt, Titman, and Wermers' (1997) three-characteristic-based model and the Carhart four-factor model fail to explain the underperformance of high investors. Furthermore, evidence of underperformance of high investors and superior performance of low investors is stronger when excess returns are based on the factor model.

To check the robustness of the obtained results, we apply nonparametric tests on medians. The medians of the excess return series and the Fama-French intercept series are reported in square brackets [ ]. The Fama-French intercept series are obtained by adding back residuals to the estimated alphas. The test on medians confirms our finding that high investors generally 
underperform low investors. In addition, the nonparametric Krushal-Wallis tests suggest that the medians differ reliably from each other across the five $C I$ portfolios for both the benchmarkadjusted returns and the Fama-French intercepts.

When the sample is divided into non-hostile takeover and hostile takeover years, it is obvious that the underperformance for high investors over low investors mainly comes from the nonhostile takeover period. In fact, low investors outperform high investors more in non-hostile takeover years than in all years. For instance, the risk-adjusted return for the $C I$-spread portfolio increases from $0.192 \%$ per month in all years to $0.312 \%(t$-value $=4.42)$ in non-hostile takeover years. Moreover, for the $C I$-spread portfolio, both the mean excess return and the Fama-French intercept are significantly positive for the non-hostile takeover period but not for the hostile takeover period. In addition, during the hostile takeover period, high investors actually perform better though not significantly better than low investors. In fact, both the difference in the excess returns and the difference in the estimated Fama-French intercepts for the $C I$-spread portfolio between non-hostile takeover and hostile takeover periods differ reliably from zero, as reported in the last column of Table 2. The significant differences are also confirmed by the nonparametric Wilcoxon Z-statistics (reported in braces \{\} ) for the test of medians to be equal across the two periods.

\section{Stock Returns Around Earnings Announcement Dates}

This section examines stock returns around earnings announcement dates and provides further evidence that the excess returns presented in the previous subsections are generated by errors in investor expectations rather than benchmark errors. Specifically, we examine the market-adjusted returns (raw returns minus the returns on the market portfolio) over a 3-day 
window centered around quarterly earnings announcement dates in each of the five years after portfolio formation. ${ }^{5}$ The earnings announcement dates are obtained from the COMPUSTAT quarterly industrial database. If the previously documented excess returns arise because investors have systematically biased expectations, then we expect that the excess returns will be substantially higher around earnings announcement dates when new information is realized.

For each quarter, the 3-day market-adjusted returns are equally weighted across all stocks in a given $C I$ portfolio to compute the portfolio's average event-date market-adjusted return. These quarterly earnings announcement date market-adjusted returns are then aggregated into annual intervals by summing up the four quarterly earnings announcement date market-adjusted returns in each of the five post-formation years. For comparison purposes we also calculate annual buyand-hold market-adjusted returns on a given $C I$ portfolio by equally weighting the individual stock's annual market-adjusted returns across all stocks in the portfolio. The individual stock's annual market-adjusted return is computed by compounding the twelve monthly market-adjusted returns on the stock.

Table 3 presents annual earnings announcement date market-adjusted returns (event returns) as well as annual buy-and-hold market-adjusted returns for the five $C I$ portfolios in each of the five years after portfolio formation for the whole sample period. It also presents the average market-adjusted returns on the $C I$-spread portfolio for the three different study periods. The table reveals a pattern of announcement date market-adjusted returns that is consistent with the pattern reported in Table 2. In particular, Panel A of Table 3 shows that in the first year

\footnotetext{
${ }^{5}$ We use daily market-adjusted returns instead of daily benchmark-adjusted returns to compute the abnormal returns around the earnings announcement dates, since the daily benchmark-adjusted returns are not readily available. However, by inspection of the monthly return behavior on the five $C I$ portfolios based on both benchmark-adjusted returns and market-adjusted returns, we find that the monthly return patterns are virtually identical between these two measures of returns. However, the magnitudes are higher for the market-adjusted returns than for the benchmark-adjusted returns, which suggests that the reported results may be conservative.
} 
following the formation date the cumulative earnings announcement date market-adjusted returns decrease monotonically with $C I$. The event-date market-adjusted return of the $C I$-spread portfolio over these 12 trading days is $0.79 \%$ which represents about $24 \%$ of the $3.33 \%$ total difference in the first-year returns between low $C I$ firms and high $C I$ firms, as summarized in Panels B and $\mathrm{C} .{ }^{6}$ The table also reveals that the substantially positive announcement date market-adjusted returns on the $C I$-spread portfolio are statistically significant in the first three years after the formation date. As one might expect, the magnitude of the excess returns decreases as the time elapsed from the formation date increases.

[Put Table 3 here].

The evidence in Panel $\mathrm{C}$ of Table 3 and test results not reported in the table indicate that earnings announcement date market-adjusted returns are substantially different from each other across the non-hostile takeover and hostile takeover periods. The observed pattern of announcement date market-adjusted returns mainly comes from the non-takeover period. In particular, the $C I$-spread announcement date market-adjusted returns are significantly positive in all five years after the formation during the non-hostile takeover years, while they are all negative and statistically indifferent from zero during the takeover years. Our evidence suggests that earnings announcement returns contribute a good portion of return differential between the low and the high abnormal investments, suggesting that the return differential is not likely to be generated by benchmark measurement errors.

\footnotetext{
${ }^{6}$ For comparison, La Porta, Lakonishok, Shleifer, and Vishny (1997) find that a significant portion of the return difference between value and glamour stocks is attributable to earnings surprises. Specifically, they find that earnings announcement return differences account for approximately 25-30 percent of the annual return differences between value and glamour stocks in the first three years after portfolio formation and approximately 15-20 percent of the return differences over years four and five after formation.
} 


\section{The Cross-Sectional Determinants of the CI-Return Relationship}

The results in the previous section indicate that in the pre- and post-hostile takeover years, there is a strong negative relation between abnormal investment expenditures and returns, whereas in the hostile takeover years, the relation becomes positive though not significant. In this section, we examine the cross-sectional determinants of this CI-return relation. Specifically, we explore how this $C I$-return relation is influenced by variables such as cash flows and debt ratios that are likely to be related to empire building tendencies. Given that the relations between $C I$ and returns appear to be different between non-hostile takeover years and hostile takeover years, we examine those years separately.

Jensen (1986) argues that those firms with the highest cash flows and the lowest leverage ratios are more likely to overinvest than less levered firms with low cash flows. If this is true, one might expect to observe a stronger negative $C I$-return relationship among firms with either high cash flows or low leverage. In the next three subsections, we test the Jensen hypothesis based on cash flows, leverage ratios, and the combined effects.

A. The Relation between Cash Flows and the Abnormal Capital Investment-Return Relation

To test whether or not cash flows have any effect on the negative $C I$-return relationship, we first form ten test portfolios based on cash flows $(\mathrm{CFs})$ and $\mathrm{CIs}$ as follows. Starting with July of year $t$, we place all stocks into two groups according to their year $t-1$ 's cash flows. Cash flow, which is scaled by total assets, is measured as operating income before depreciation minus interest expenses, taxes, preferred dividends, and common dividends. If a firm's $C F$ is below the median $C F$ of the year, it is designated as part of the low $C F$ group; otherwise it is placed in the high $C F$ group. Within each $C F$ group, stocks are equally sorted into quintiles based on their 
year $t$-1's $C I \mathrm{~s}$ in an ascending order. As a result, we have a total of ten portfolios based on the $C F$ and $C I$ classifications. The returns of a particular stock are adjusted for its corresponding characteristic-based benchmark portfolio returns. We then calculate each portfolio's valueweighted monthly excess returns from July of year $t$ to June of year $t+1$, and then rebalance the portfolios in June of year $t+1$.

We further form two $C I$-spread portfolios, one for the low $C F$ group and the other for the high $C F$ group. In addition, we form one $H-L$ (High minus $L$ ow) $C F C I$-spread portfolio. The $C I$ spread portfolio denotes a zero-investment portfolio that has a one-dollar long position in the lowest two $C I$ portfolios and a one-dollar short position in the highest two $C I$ portfolios for a given $C F$ group. The $H-L C F C I$-spread portfolio is the one that has a long position in the high $C F C I$-spread portfolio and a short position in the low $C F C I$-spread portfolio. Forming portfolios in this way allows us to determine whether there is a differential pattern in the $C I$ return relation between low $C F$ firms and high $C F$ firms after controlling for the firm characteristics. We also regress $C I$ portfolio returns on the Carhart four factors to control for risk. The Jensen agency argument suggests that the return on the $H-L C F C I$-spread portfolio will be positive.

The results reported in Table 4 are consistent with this agency explanation. Table 4 presents the monthly mean excess returns, the regression results on the ten characteristic-adjusted $C F / C I$ portfolios and the $C I$-spread portfolios in each of the three study periods, and the difference between non-hostile takeover and hostile takeover periods. The median values and the $Z$ statistics of the nonparametric Wilcoxon test for the $C I$-spreads are reported in square brackets [ ] and braces \{\} , respectively. The last three rows in Table 4 provide the $F$-values of the Wilks' Lambda statistic for the test of whether means are equal across the CI portfolios. 
[Put Table 4 here]

The results from the all-years sample indicate that the mean excess returns for high $C F$ firms monotonically decrease with abnormal capital investments. This is not, however, the case for firms with low cash flows. Indeed, in the low $C F$ subsample, the lowest $C I$ portfolio experiences a significant negative return. In addition, the positive $C I$-spread is significant only for the high $C F$ group (the $C I$-spread is $0.227 \%$ per month for the high $C F$ group while it is only $0.078 \%$ for the low $C F$ group). However, the difference in returns between the high and the low $C F C I$ spreads $(0.149 \%$ per month $)$ is not statistically significant, as is also evidenced by the test result of Wilks' Lambda statistic on the mean returns of the CI-spread portfolios across the two cash flow groups.

These results get somewhat stronger when we control for risk using the Carhart four-factor model. The Wilks' Lambda test result suggests that the estimated Fama-French intercepts are significantly different from each other across the five $C I$ portfolios for both cash flow groups. The risk-adjusted return is significant only for the $C I$-spread portfolio of the high $C F$ group with a value of $0.256 \%$ per month, and is insignificant for the low $C F$ group with a value of $0.059 \%$ per month. This suggests that among firms with a high level of free cash flows, high $C I$ firms tend to underperform low $C I$ firms substantially, whereas the underperformance is much weaker among firms with a low level of free cash flows. A formal test on the $H-L C F C I$-spread portfolio indicates that a return difference of $0.197 \%$ per month in the $C I$ - spreads between the high and the low $C F$ firms is marginally significant at the ten percent level. It suggests that after accounting for the characteristics and risk factors, the negative $C I$-return relationship is stronger among firms with higher levels of cash flows than among firms with lower levels of cash flows, which supports the managerial agency/overinvestment explanation suggested by Jensen (1986). 
The results from non-takeover years versus takeover years clearly suggest that the above $C I$ return pattern mainly comes from non-takeover years rather than from takeover years. Specifically, the estimated Fama-French intercepts differ reliably from each other across the five $C I$ portfolios for both $C F$ groups for the non-hostile takeover period, but it is not the case for the hostile takeover period. Moreover, both the difference in the mean excess returns and the difference in the Fama-French intercepts of the high $C F C I$-spread between the non-takeover and takeover periods are reliably different from zero. The evidence of the nonparametric test of medians (not reported here) also supports this conclusion.

B. The Relation between Debt Ratios and the Abnormal Capital Investment-Return Relation This same procedure described above is also used to determine whether a firm's debt ratio affects the $C I$-return relation. We form ten portfolios based on the debt-to-assets ratio $(D A)$ and the capital investment $(C I)$ classifications and then form two $C I$-spread portfolios and one $H-L$ $D A C I$-spread portfolio. The debt-to-assets ratio is defined as the ratio of long-term debt over the sum of long-term debt plus the market value of firm's equity. If a firm's debt-to-assets ratio is below the median debt-to-assets ratio of the year, the firm is assigned to the low debt group; otherwise it is assigned to the high debt group. The Jensen agency argument suggests that the $\mathrm{H}$ L DA CI-spread should be negative.

Table 5 reports the average returns on benchmark-adjusted $D A / C I$ portfolios, the regression results on the Carhart four factors, and the across periods tests on the mean returns and the Fama-French intercepts. The results from all years show that the characteristics-adjusted returns monotonically decrease with the $C I$ measures for the low $D A$ sample but not for the high $D A$ sample. In addition, the characteristics-adjusted returns on the $C I$-spread portfolios are 
significantly positive for the low $D A$ sample $(0.225 \%$ per month) but not for the high $D A$ sample (0.099\% per month). The difference in returns between the high $D A$ and the low $D A C I$-spreads $(H-L D A C I$-spread $=-0.126 \%$ per month) is not statistically significant, but becomes marginally significant at the ten percent level when we control for risks using the Carhart four-factor model. The test results also suggest that the risk-adjusted returns are significantly different from each other across the five $C I$ portfolios for both $D A$ groups. In addition, both the difference in excess returns and the difference in the estimated Fama-French intercepts between the non-hostile takeover and hostile takeover periods are significantly different from zero, for both the high $D A$ and the low $D A C I$-spreads. Again, this evidence and the evidence from the nonparametric test of medians are driven by the non-takeover years and are consistent with the agency explanation.

[Put Table 5 here]

C. The Combined Effect of Cash Flow and Debt Ratio on the Abnormal Capital InvestmentReturn Relation

In this section we examine the combined effects of cash flows and debt by using a FamaMacBeth (1973) approach. Specifically, we estimate the following Fama-MacBeth regression models:

Model 1: $R_{i t}=\lambda_{0, t}+\lambda_{1, t} C I_{i, t-1}+\lambda_{2, t} C I_{i, t-1} \times D C F_{i, t-1}+\varepsilon_{i, t}, \quad t=1, \ldots, T$, Model 2: $R_{i t}=\lambda_{0, t}+\lambda_{1, t} C I_{i, t-1}+\lambda_{3, t} C I_{i, t-1} \times D D A_{i, t-1}+\varepsilon_{i, t}, \quad t=1, \ldots, T$, Model 3: $R_{i t}=\lambda_{0, t}+\lambda_{1, t} C I_{i, t-1}+\lambda_{2, t} C I_{i, t-1} \times D C F_{i, t-1}+\lambda_{3, t} C I_{i, t-1} \times D D A_{i, t-1}+\varepsilon_{i, t}, \quad t=1, \ldots, T$, where $R_{i t}$ is the benchmark-adjusted value-weighted return on individual stock $i$ in month $t$. It is weighted by the firm's market value relative to the total market value for a given $C I$ rank it belongs to in a given year, which is basically what we have done in Tables 4 and $5 . C I_{i, t-1}$ is the abnormal capital investment measure for firm $i$. To be consistent with our results reported in 
Tables 4 and 5, we use dummy variables $D C F$ and $D D A$ to assign a firm's cash flow $(C F)$ and debt to assets ratio $(D A)$. If a firm's $C F$ is above the median $C F$ of the year, then $D C F$ equals one and zero otherwise. $D D A$ is defined in the same way. In addition, to reduce the impact from the extreme outliers, the top and bottom $1.5 \%$ of the observations (based on characteristicsadjusted returns) are excluded from the sample. The Jensen (1986) managerial agency/overinvestment explanation predicts that $\lambda_{1}<0, \lambda_{2}<0$, and $\lambda_{3}>0$.

The test results are presented in Table 6. The results from Model 1 and Model 2 are basically consistent with those reported in Tables 4 and 5. More specifically, the results from all years indicate that the regression coefficients on both $C I$ and $C I \times D C F$ are significantly negative. The results suggest that the $C I$-return relationship is negative and that this negative relationship is significantly stronger for high $C F$ firms, consistent with our findings in Table 4. We also find that the regression coefficient on $C I$ is significantly negative at the five percent level whereas the regression coefficient on $C I \times D D A$ is significantly positive at the ten percent level. The results indicate that the $C I$-return relationship is strongly negative and that this negative relationship is marginally stronger for low $D A$ firms, consistent with our findings in Table 5 . When both $C I \times D C F$ and $C I \times D D A$ are simultaneously considered in the regression, the coefficients on $C I$ and $C I \times D C F$ are still significantly negative, the coefficient on $C I \times D D A$ remains positive but it becomes insignificant. ${ }^{7}$

[Put Table 6 here]

\footnotetext{
${ }^{7}$ Notice that the independent variable in Equation (4) is characteristics-adjusted returns without taking into account the factor risks. Using the characteristics-adjusted returns, the returns on the $H-L C F C I$-spread portfolio and on the $H$ - $L D A C I$-spread portfolio are not statistically significant in Tables 4 and 5, respectively. If we exclude the top and the bottom $2.0 \%$ of the observations based on characteristics-adjusted returns, all slope coefficients are statistically significant for both the all-years sample and the non-hostile takeover years sample with predicted signs.
} 
The results from the non-hostile takeover period versus the hostile takeover period suggest that the impact of cash flow and debt ratio on the negative $C I$-return relationship primarily comes from the non-hostile takeover period. In sum, the Fama-MacBeth regression results confirm our findings in the previous subsections that the outperformance of low $C I$ firms over high $C I$ firms is stronger for those firms with the least financial constraints and that these results exist only in the non-hostile takeover period.

\section{Robustness of the $C I$-Return Relation}

\section{A. The Contrarian Effect}

The firms in our sample with high abnormal capital expenditures tend to have experienced above average stock returns in the preceding years. For instance, the past five-year raw returns on the five $C I$ portfolios ranked from the lowest $C I$ to the highest $C I$ are $81.53 \%, 114.50 \%$, $132.85 \%, 145.64 \%$, and $153.77 \%$, respectively. Hence, it is possible that the capital investment effect that we have documented is driven by the contrarian effect that was previously documented by De Bondt and Thaler (1985).

To examine this more closely, we independently sort firms into quintiles determined by both the past 5-year returns of their stocks $(P R)$ and the level of their abnormal capital expenditures $(C I)$. We also form five $C I$-spread portfolios and five $P R$-spread portfolios. ${ }^{8}$ The returns on the resulting portfolios are reported in Table 7. The results indicate that there is clearly an abnormal capital expenditure effect (i.e. low $C I$ firms outperform high $C I$ firms) that is independent of the contrarian effect in all years and in non-hostile takeover years. For instance, the $C I$-spread is generally positive for a given $P R$ rank as shown in both Panel A and Panel B of Table 7; and the

\footnotetext{
${ }^{8}$ Refer to Table 7 for the detailed description of portfolio construction.
} 
average $C I$-spread is statistically significant with a value of $0.285 \%$ per month as shown in Panel B. In addition, our unreported test show that the average $C I$-spread differs reliably across the non-takeover and takeover periods while the average $P R$-spread does not. The evidence here suggests that after controlling for firm characteristics and the contrarian effect, the $C I$ effect remains strong, especially for the non-hostile takeover period.

However, our results also reveal a contrarian effect, which is weak and statistically insignificant after controlling for the $C I$ effect. ${ }^{9}$ In addition, as shown in Panel $\mathrm{C}$ of Table 7, the contrarian effect is negative in the hostile takeover years when the $C I$ effect is negative. Indeed, unconditionally (that is, when we do not sort on $C I$ ) our unreported result indicates that the contrarian effect is negative in the hostile takeover years. Hence, our evidence suggests that it is more likely that the contrarian effect is caused by the capital investment effect than vice versa.

[Put Table 7 here]

\section{B. The Effect of New Equity Offerings}

Past research documents that companies that issue new equity, either initial public offerings (IPOs) or seasoned equity offerings (SEOs), subsequently realize poor long-run stock price performance (Loughran and Ritter (1995), Cai and Wei (1997) and others). Firms that issue new equity generally have higher levels of capital expenditures (relative to total assets) than nonissuing firms (Loughran and Ritter (1997)). Our own evidence also indicates that firms that issue equity in the previous year invest more than those that do not have new equity issues. Specifically, the value-weighted average and the simple average of $C I$ measures for firms in our

\footnotetext{
${ }^{9}$ To check the robustness of our results, (1) we also rank the stocks based on the past 3-year returns instead of the past 5-year returns, and (2) we sort the stocks first based on the past returns and then the CI-measures or the reverse. The unreported results indicate that the return patterns are almost identical to those reported in Table 7. More specifically, there exists a capital investment effect that is independent of the contrarian effect.
} 
sample that have not issued new equity in previous year are 0.014 and 0.091 , respectively, while those averages for firms that have issued new equity in previous years are 0.071 and 0.170 , respectively. Adverse selection models, like Myers and Majluf (1984), suggest that the negative stock returns associated with high capital investments should be concentrated in those firms that fund their capital expenditures with SEOs. To examine whether the observed negative abnormal investment/return relation is attributable to these new equity offering firms, we reexamine the benchmark-adjusted return differences between high and low investors that have not issued stock in any year from year -5 to year -1 .

The test results are reported in Table 8. The underperformance of high investors relative to low investors remains the same. Specifically, the benchmark-adjusted return on the $C I$-spread portfolio in the all-years period is $0.186 \%$ per month $(2.23 \%$ per year) with a $t$-value of 3.34 . The corresponding risk-adjusted return is $0.208 \%$ per month $(2.50 \%$ per year) with a $t$-value of 3.43. Again, the $C I$ effect is significant in non-takeover years but it reverses and is insignificant in takeover years. This evidence suggests that the observed negative $C I$-return relation is not driven by the SEO effect and is also supported by evidence from test on medians. ${ }^{10}$

[Put Table 8 here].

\section{Conclusion}

This paper documents a negative relation between abnormal capital investments and future stock returns. Firms that increase their level of capital investment the most tend to achieve lower

\footnotetext{
${ }^{10}$ The unreported results indicate that the benchmark-adjusted return pattern on the $C I$-spread portfolio that excludes firms that have issued new equity in any of the past five years also persists for at least five years. Specifically, the returns are $2.49 \%(\mathrm{t}=3.23)$ for year $1,2.67 \%(\mathrm{t}=3.11)$ for year $2,2.15 \%(\mathrm{t}=2.67)$ for year $3,2.26 \%$ $(\mathrm{t}=2.47)$ for year 4 , and $1.71 \%(\mathrm{t}=1.98)$ for year 5 and the five-year cumulative benchmark-adjusted return is $9.91 \%$
} 
stock returns for five subsequent years. Our evidence suggests that the negative relation between abnormal investments and stock returns cannot be explained by either the risks or the characteristics of the firms and are independent of the previously documented long-term return reversal and secondary equity issue anomalies.

In theory, increased investment expenditures can provide both favorable and unfavorable information. The favorable information is that the firm that invests more is likely to have better investment opportunities and the unfavorable information is that firms that invest more are more likely to be managed by individuals who have a tendency to over-invest. Our evidence is consistent with the hypothesis that investors tend to underestimate the importance of the unfavorable information about managerial intentions. First, we find that the negative abnormal capital investment/return relation reverses in the $1984-1989$ period, a period in which an active takeover market disciplined firms that over-invested. Second, we find that the negative $C I$ return relation is stronger for firms with higher cash flows or/and lower debt ratios, which probably have a greater tendency to overinvest.

There are, of course, other potential explanations for the negative CI-return relation that we did not consider. One possibility is that stocks have time varying rates of return and firms choose to invest more when the expected return on their stock, or in other words their cost of equity capital, is unusually low. For example, if the market unduly rewards some firms for high levels of investment (e.g., the internet firms in the late 1990s), then one might expect those firms to increase their investments and subsequently realize low returns. In this case, the low future returns can be viewed as a cause, rather than the effect, of high abnormal capital expenditures. Lamont (2000) examined this hypothesis using aggregate nonresidential U.S. investment data

$(\mathrm{t}=3.00)$. If we exclude firms that have issued new equity in the formation year only, the results are virtually 
and found support for this hypothesis. More recently, Baker, Stein, and Wurgler (2002) explore the hypothesis that the degree to which a firm is over or undervalued affects investment choices. While this possibility clearly warrants future research, it is not clear whether this explanation is consistent with either our time-series or cross-sectional findings.

A similar argument can be made within the context of a rational model, where future expected rates of return are determined by risk rather than mispricing. For example, $\mathrm{Li}$, Vassalou, and Xing (2002) propose and test a model where a positive shock to the marginal product of capital, which can increase investment, simultaneously decreases risk, which would reduce the expected rate of return. Since their tests are designed to explain the returns of size and book-to-market sorted portfolios, they cannot be directly related to our tests that examine excess returns relative to benchmarks that are based on these same characteristics. However, it is possible that the excess return associated with abnormal investment expenditures is in fact related to risk factors that are unrelated to the factors we consider. A careful consideration of this possibility is also a potentially fruitful topic for future research.

identical to those reported here and in Table 8. 


\section{References}

Baker, Malcolm, Jeremy C. Stein, and Jeffrey Wurgler, 2002, "When does the market matter? Stock prices and the investment of equity-dependent firms," Harvard Business School working paper.

Banz, Rolf W., and William Breen, 1986, " Sample dependent results using accounting and market data: Some evidence," Journal of Finance 41, 779-793.

Blose, Laurence E and Joseph C.P. Shieh, 1997, "Tobin's q-ratio and market reaction to capital investment announcements," Financial Review 32, 449-476.

Cai, Jun and K.C. John Wei, 1997 "The investment and operating performance of Japanese IPO Firms," Pacific-Basin Finance Journal 5, 389-417.

Carhart, Mark M., 1997, “On persistence in mutual fund performance," Journal of Finance 52, 57-83.

Chopra, Navin, Josef Lakonishok, and Jay Ritter, 1992, "Measuring abnormal returns: Do stocks overreact?" Journal of Financial Economics 31, 235-268.

Daniel, Kent, Mark Grinblatt, Sheridan Titman, and Russ Wermers, 1997, "Measuring mutual fund performance with characteristic-based benchmarks," Journal of Finance 52, 1035-1058.

Daniel, Kent and Sheridan Titman, 1997, "Evidence on the characteristics of cross sectional variation in stock returns," Journal of Finance 52, 1-33.

Daniel, Kent D., Sheridan Titman, and K.C. John Wei, 2001, "Explaining the cross-section of stock returns in Japan: factors or characteristics?" Journal of Finance 56, 743-766.

De Bondt, Werner F.M. and Richard H. Thaler, 1985, “ Does the stock market overreact?" Journal of Finance 40, 793-805.

Fama, Eugene F. and Kenneth R. French, 1992, "The cross-section of expected stock returns," Journal of Finance 47, 427-465.

Fama, Eugene F. and Kenneth R. French, 1993, "Common risk factors in the returns on stocks and bonds," Journal of Financial Economics 33, 3-56.

Fama, Eugene F., and James MacBeth, 1973, "Risk, return and equilibrium: Empirical tests," Journal of Political Economy, 81, 607-636.

Fazzari, Steven M., Ron G. Hubbard and Bruce C. Peterson, 1988, "Financing constraints and corporate investment," Brookings Papers on Economic Activity 1, 141-205. 
Holmstrom, Bengt and Steven N. Kaplan, 2001, "Corporate governance and merger activity in the U.S.: Making sense of the 1980s 1990s," Working paper, MIT and University of Chicago.

Hubbard, R. Glenn, 1998, "Capital-market imperfections and investment," Journal of Economic Literature 36, 193-225.

Ikenberry, David, Josef Lakonishok, and Theo Vermaelen, 1995, "Market underreaction to open market share repurchases," Journal of Financial Economics 39, 181-208.

Jensen, Michael, 1986, "Agency costs of free cash flow, corporate finance, and takeover," American Economic Review 76, 323-329.

Jegadeesh, Narasimhan, and Sheridan Titman, 1993, "Returns to buying winners and selling losers: Implications for stock market efficiency," Journal of Finance 48, 65-91.

Jegadeesh, N., and S. Titman, 2001, "Profitability of momentum strategies: an evaluation of alternative explanations," Journal of Finance 56, 699-720.

La Porta, Rafael, Josef Lakonishok, Adnrei Shleifer, and Robert Vishny, 1997, "Good news for value stocks: Further evidence on market efficiency," Journal of Finance 52, 859-874

Lamont, Owen, 2000, "Investment plans and stock returns," Journal of Finance 55, 2719-2745.

Li, Qing, Maria Vassalou, and Yuhang Xing, 2002, “An investment-growth asset pricing model," Working paper, Columbia University.

Loughran, Tim and Jay Ritter, 1995, “The new issues puzzle," Journal of Finance 50, 23-52.

Loughran, Tim and Jay Ritter, 1997, “The operating performance of firms conducting seasoned equity offerings," Journal of Finance 52, 1823-1850.

McConnell, John J. and Chris J. Muscarella, 1985, "Corporate capital investment decisions and the market value of the firms," Journal of Financial Economics 14, 399-422.

Morck, Robert, Andrei Shleifer and Robert Vishny, 1990, “The stock market and investment: Is the market a side-show?" Brookings Papers on Economic Activity 2, 157-215.

Myers, S.C. and N.S. Majluf, 1984, "Corporate financing and investment decisions when firms have information that investors do not have," Journal of Financial Economics 13, 187-221.

Teoh, S.H. and T. J. Wong, 2002, "Why New Issues and High-Accrual Firms Underperform: The Role of Analysts' Credulity," Review of Financial Studies 15, 869-900.

Vogt, Stephen C., 1997, "Cash flow and capital spending: Evidence from capital expenditure announcement," Financial Management, 26, 44-57. 
TABLE 1

Excess Return Distribution of Capita Investment (CI) Portfolios and the Year-to-Year Returns on the CI-Spread Portfolio: July 1973 to June 1996

Panel A presents the distribution of excess returns on all five CI portfolios and the CI-spread portfolio. The statistics include the monthly mean excess returns (Mean), the standard deviation (Std Dev), the maximum (Max), the 75th percentile (Q3), the median (Median), the 25th percentile (Q1), and the minimum (Min) of the excess returns.

At each June of year $t$, all stocks are sorted into quintiles based on their CI measures in ascending order to form five CI portfolios. Value-weighted monthly excess returns on a portfolio are calculated from July of year $t$ to June of year $t+1$, where the excess return on an individual stock at time $t$ is calculated by subtracting the characteristic-based benchmark portfolio's return from the stock's return at time t. The CI-spread denotes a zero-investment portfolio that has a long position in the lowest two CI portfolios and a short position in the highest two CI portfolios. The return series for this portfolio is calculated by subtracting the sum of the returns on the highest two portfolios from that on the lowest two CI portfolios, and then divide by 2 . All portfolios are rebalanced each year. Returns are the in percentage form.

Panel B presents the year-by-year returns on the benchmark-adjusted CI-spread portfolio. The return in year $t$ is calculated as a 12-month compounded return from July of year $\mathrm{t}$ to June of year $\mathrm{t}+1$. For each formation period, the Panel reports the returns (in percentage) on the CI-spread portfolio in years 1, 2, 3, 4 and 5 after formation and the five-year cumulative returns. The last row reports the arithmetic means across periods with the t-statistics in parentheses. $*$ and ${ }^{* *}$ represent significant at the 0.10 and 0.05 levels, respectively.

Panel A: Distributional characteristics of CI portfolios

\begin{tabular}{|c|c|c|c|c|c|c|c|}
\hline CI Portfolio & Mean & Std Dev & Max & Q3 & Median & Q1 & Min \\
\hline Lowest & 0.042 & 0.010 & 3.375 & 0.658 & 0.062 & -0.652 & -3.112 \\
\hline 2 & $0.083^{* *}$ & 0.007 & 2.257 & 0.468 & 0.103 & -0.310 & -2.760 \\
\hline 3 & 0.055 & 0.006 & 1.841 & 0.388 & 0.031 & -0.297 & -2.066 \\
\hline 4 & $-0.083^{* *}$ & 0.005 & 1.382 & 0.263 & -0.056 & -0.380 & -1.880 \\
\hline 5 & $-0.127 * *$ & 0.010 & 2.608 & 0.553 & -0.081 & -0.789 & -4.080 \\
\hline CI-spread & $0.168^{* *}$ & 0.009 & 3.302 & 0.779 & 0.119 & -0.462 & -2.629 \\
\hline
\end{tabular}

Panel B: The Year-to-Year Returns on the Benchmark-Adjusted CI-Spread Portfolio

\begin{tabular}{|c|c|c|c|c|c|c|}
\hline $\begin{array}{c}\text { Formation } \\
\text { Year }\end{array}$ & $\begin{array}{c}\text { Return in } \\
\text { Year } 1\end{array}$ & $\begin{array}{l}\text { Return in } \\
\text { Year } 2\end{array}$ & $\begin{array}{c}\text { Return in } \\
\text { Year } 3\end{array}$ & $\begin{array}{c}\text { Return in } \\
\text { Year } 4\end{array}$ & $\begin{array}{c}\text { Return in } \\
\text { Year } 5\end{array}$ & $\begin{array}{c}\text { Cumulative } \\
\text { Return }\end{array}$ \\
\hline 1973 & -0.95 & 9.22 & 2.65 & 5.79 & 8.60 & 25.32 \\
\hline 1974 & 7.41 & 3.53 & 4.88 & 8.05 & 5.30 & 29.17 \\
\hline 1975 & 3.16 & 5.78 & 7.95 & 5.49 & 6.73 & 29.12 \\
\hline 1976 & 5.41 & 7.90 & 4.97 & 7.02 & 1.04 & 26.34 \\
\hline 1977 & 7.71 & 3.84 & 6.43 & 0.45 & -3.92 & 14.51 \\
\hline 1978 & 3.43 & 5.90 & 1.29 & -3.67 & 0.99 & 7.95 \\
\hline 1979 & 5.44 & 0.60 & -1.48 & 0.00 & 1.43 & 6.00 \\
\hline 1980 & 0.62 & -1.31 & 0.28 & 1.42 & -4.38 & -3.38 \\
\hline 1981 & -1.56 & 0.33 & 1.55 & -4.34 & -0.67 & -4.69 \\
\hline 1982 & 0.93 & 1.09 & -4.29 & -0.70 & -1.66 & -4.63 \\
\hline 1983 & 1.06 & -4.02 & -0.92 & -1.58 & -2.26 & -7.71 \\
\hline 1984 & -3.95 & -1.21 & -1.35 & -2.03 & -3.12 & -11.67 \\
\hline 1985 & -1.08 & -1.19 & -1.81 & -3.24 & -1.83 & -9.15 \\
\hline 1986 & -0.75 & -2.01 & -3.23 & -1.58 & 5.03 & -2.54 \\
\hline 1987 & -1.19 & -1.00 & -2.04 & 3.87 & 1.85 & 1.50 \\
\hline 1988 & -0.94 & -2.39 & 3.76 & 2.09 & 1.65 & 4.17 \\
\hline 1989 & -2.57 & 3.78 & 2.18 & 2.55 & 6.88 & 12.81 \\
\hline 1990 & 3.45 & 1.40 & 2.23 & 6.50 & 5.25 & 18.83 \\
\hline 1991 & 2.00 & 2.54 & 6.62 & 6.60 & 4.25 & 22.00 \\
\hline 1992 & 1.54 & 6.49 & 6.42 & 4.27 & & \\
\hline 1993 & 6.52 & 5.97 & 4.11 & & & \\
\hline 1994 & 6.36 & 4.54 & & & & \\
\hline 1995 & 4.52 & & & & & \\
\hline $\begin{array}{c}\text { Average } \\
\text { (t-statistic) }\end{array}$ & $\begin{array}{c}2.02 \\
(2.86)\end{array}$ & $\begin{array}{c}2.26 \\
(2.88)\end{array}$ & $\begin{array}{c}1.91 \\
(2.46)\end{array}$ & $\begin{array}{c}1.85 \\
(2.10)\end{array}$ & $\begin{array}{c}1.64 \\
(1.81)\end{array}$ & $\begin{array}{c}8.10 \\
(2.55)\end{array}$ \\
\hline
\end{tabular}


TABLE 2

Mean Excess Returns and Regression Results for the Characteristic-Adjusted

Capital Investment Portfolio Returns on the Carhart Four Factors

This table presents mean excess returns (Mean Return) and intercept estimates (FF alpha) from the following regression model:

$$
R_{p, t}=\alpha_{p}+\beta_{H M L, p} R_{H M L, t}+\beta_{S M B, p} R_{S M B, t}+\beta_{M k t, p}\left(R_{M k t, t}-R_{f t}\right)+\beta_{\mathrm{Pr} 1 y r, p} R_{\mathrm{Pr} 1 y r, t}+\varepsilon_{p, t}
$$

The dependent variable $\mathrm{R}_{\mathrm{p}, \mathrm{t}}$ is the excess return on a given CI portfolio $\mathrm{p}$ in month t. $\mathrm{R}_{\mathrm{ft}}$ is the risk-free rate in month t. $\mathrm{R}_{\mathrm{HML}, \mathrm{t}}$ is the return on the HML (High Minus Low) factor portfolio. $\mathrm{R}_{\mathrm{SMB}, \mathrm{t}}$ is the return on the SMB (Small Minus Big) size factor portfolio. $\mathrm{R}_{\mathrm{Mk}, \mathrm{t}}$ is the return on the Mkt (Market) factor portfolio. $\mathrm{R}_{\mathrm{Pr} l y, t}$ is the return on the PR1YR (high minus low prior-year return) momentum portfolio. Refer to Table 1 for detailed portfolio construction. Returns are in the percentage form.

All years refer to the whole sample period (July 1973 to June 1996). Takeover years refer to the period of time from 1984 to 1989. Non-takeover years refer to the period that excludes the takeover years. Difference refers to the difference in returns between the non-takeover and the takeover periods. The medians of the excess return series and the FF alpha series are reported in square brackets [ ]. The FF alpha series is defined by adding back the residuals to the estimated intercept. The nonparametric Wilcoxon Z-statistics for the test of medians to be equal across the two sub-periods are reported in braces \{\} . The F-values of Wilks' Lambda statistic for the test of means to be equal and the Chi-square values of the nonparametric Kruskal-Wallis test for the test of medians to be equal across the five CI portfolios are reported in the last two rows with p-values in parentheses.

\begin{tabular}{|c|cc|cc|cc|cc|}
\hline Portfolio & \multicolumn{2}{|c|}{ All Years } & \multicolumn{2}{c|}{ Non-takeover Years } & \multicolumn{2}{c|}{ Takeover Years } & \multicolumn{2}{c|}{ Difference } \\
\hline CI & Mean Return & FF alpha & Mean Return & FF alpha & Mean Return & FF alpha & Mean Return & FF alpha \\
\hline Lowest & 0.042 & -0.012 & $0.132^{*}$ & 0.063 & $-0.213^{* *}$ & $-0.231^{* *}$ & $0.345^{* *}$ & $0.294^{* *}$ \\
& {$[0.062]$} & {$[-0.010]$} & {$\left[0.173^{*}\right]$} & {$[0.050]$} & {$\left[-0.328^{* *}\right]$} & {$\left[-0.352^{* *}\right]$} & $\left\{-2.537^{* *}\right\}$ & $\left\{-2.218^{* *}\right\}$ \\
\hline \multirow{2}{*}{} & $0.083^{* *}$ & $0.119^{* *}$ & $0.110^{* *}$ & $0.161^{* *}$ & 0.006 & 0.032 & 0.104 & 0.129 \\
& {$\left[0.103^{* *}\right]$} & {$\left[0.103^{* *}\right]$} & {$[0.139]^{* *}$} & {$\left[0.137^{* *}\right]$} & {$[-0.007]$} & {$[0.061]$} & $\{-0.960\}$ & $\{-1.200\}$ \\
\hline \multirow{2}{*}{0.055} & 0.058 & $0.079^{*}$ & $0.078^{*}$ & -0.011 & -0.027 & -0.090 & -0.105 \\
& {$[0.031]$} & {$[0.034]$} & {$\left[0.026^{*}\right]$} & {$\left[0.034^{*}\right]$} & {$[0.041]$} & {$[0.005]$} & $\{-0.972\}$ & $\{-1.201\}$ \\
\hline 4 & $-0.083^{* *}$ & $-0.103^{* *}$ & $-0.133^{* *}$ & $-0.164^{* *}$ & 0.058 & 0.051 & $-0.191^{* *}$ & $-0.215^{* *}$ \\
& {$\left[-0.056^{* *}\right]$} & {$\left[-0.066^{* *}\right]$} & {$\left[-0.094^{* *}\right]$} & {$\left[-0.174^{* *}\right]$} & {$[0.044]$} & {$[0.030]$} & $\left\{2.470^{* *}\right\}$ & $\left\{2.807^{* *}\right\}$ \\
\hline Highest & $-0.127^{* *}$ & $-0.173^{* *}$ & $-0.180^{* *}$ & $-0.237^{* *}$ & 0.023 & -0.001 & -0.203 & $-0.236^{*}$ \\
& {$\left[-0.081^{*}\right]$} & {$\left[-0.131^{* *}\right]$} & {$\left[-0.120^{* *}\right]$} & {$\left[-0.166^{* *}\right]$} & {$[0.082]$} & {$[-0.034]$} & $\left\{1.883^{*}\right\}$ & $\left\{1.950^{*}\right\}$ \\
\hline CI-spread & $0.168^{* *}$ & $0.192^{* *}$ & $0.277^{* *}$ & $0.312^{* *}$ & -0.144 & -0.124 & $0.421^{* *}$ & $0.436^{* *}$ \\
& {$\left[0.119^{* *}\right]$} & {$\left[0.202^{* *}\right]$} & {$\left[0.338^{* *}\right]$} & {$\left[0.343^{* *}\right]$} & {$\left[-0.281^{* *}\right]$} & {$\left[-0.278^{*}\right]$} & $\left\{-3.958^{* *}\right\}$ & $\left\{-4.160^{* *}\right\}$ \\
\hline Wilks' Lambda & 2.08 & 4.68 & 4.63 & 6.57 & 1.24 & 1.23 & & \\
(p-value) & $(0.026)$ & $(0.001)$ & $(0.001)$ & $(<0.001)$ & $(0.300)$ & $0.305)$ & \\
\hline Kruskal-Wallis test & 14.29 & 24.97 & 25.37 & 35.90 & 6.97 & 8.74 & & \\
(p-value) & $(0.006)$ & $(<0.001)$ & $(<0.001)$ & $(<0.001)$ & $(0.138)$ & $0.068)$ & \\
\hline
\end{tabular}


TABLE 3

Annual Cumulative Earnings Announcement Date Returns and Annual Buy-and-Hold Returns on CI Portfolios

At the end of each June between 1973 and 1995, five CI portfolios are formed based on the CI measure. The CI-spread is a zero-cost portfolio that has a one dollar long position in the lowest two CI portfolios and a one dollar short position in the highest two CI portfolios. The returns presented in the table are averages over all formation periods. Panel A contains equally weighted earnings announcement date returns (event returns) for each portfolio. These are measured quarterly over a 3-day window $(\tau-1, \tau+1)$ around the announcement date $\tau$ and are then summed up over the four quarters in each of the first five post-formation years (Q01-Q04, .., Q17-Q20). Panel B contains equally weighted annual returns on portfolios in year $t$ after formation, $t=1,2,3,4,5$. The annual return is measured as the compounded return on monthly basis. Panel $\mathrm{C}$ summarizes the annualized announcement returns and annual returns on CI-spread portfolio for the three different sample periods in year $\mathrm{t}$ after formation, $\mathrm{t}=1,2,3,4,5$. Ratio is measured by dividing announcement return by annual return. All years refer to the whole sample period (July 1973 to June 1996). Takeover years refer to the period of time from 1984 to 1989. Non-takeover years refer to the period that excludes the takeover years. All returns are market-adjusted returns and are expressed in percentage. ${ }^{*}$ and $* *$ represent significant at the 0.10 and 0.05 levels, respectively.

\begin{tabular}{|c|c|c|c|c|c|c|}
\hline Portfolio & CI1 & $\mathrm{CI} 2$ & $\mathrm{CI} 3$ & CI4 & CI5 & CI-spread \\
\hline \multicolumn{7}{|c|}{ Panel A: Event Returns (All Years) } \\
\hline Year 1 & 1.941 & 1.207 & 0.931 & 0.813 & 0.751 & $0.792 * *$ \\
\hline Year 2 & 1.435 & 1.058 & 0.764 & 0.704 & 0.705 & $0.542 * *$ \\
\hline Year 3 & 1.132 & 0.982 & 0.584 & 0.567 & 0.626 & $0.460 * *$ \\
\hline Year 4 & 1.049 & 0.696 & 0.466 & 0.409 & 0.621 & 0.358 \\
\hline Year 5 & 1.098 & 0.718 & 0.339 & 0.482 & 0.665 & 0.334 \\
\hline \multicolumn{7}{|c|}{ Panel B: Annual Returns (All Years) } \\
\hline Year 1 & 10.654 & 8.322 & 6.615 & 6.244 & 6.070 & $3.330 * *$ \\
\hline Year 2 & 10.202 & 8.207 & 6.497 & 5.766 & 5.742 & $3.450 * *$ \\
\hline Year 3 & 7.801 & 5.674 & 4.282 & 3.648 & 3.377 & $3.225 * *$ \\
\hline Year 4 & 7.496 & 5.545 & 4.251 & 3.822 & 3.017 & $3.056 * *$ \\
\hline Year 5 & 7.316 & 5.800 & 5.041 & 4.687 & 3.088 & $2.671 * *$ \\
\hline
\end{tabular}

Panel C: Ratios of Earnings Announcement Date Market-adjusted Returns to Annual Market-adjusted Return on the CISpread Portfolio

\begin{tabular}{|c|c|c|c|c|c|c|c|c|}
\hline & \multicolumn{3}{|c|}{ All Years } & \multicolumn{2}{c|}{ Non-takeover Years } & \multicolumn{2}{c|}{ Takeover Years } \\
\hline $\begin{array}{c}\text { CI-Spread } \\
\text { Portfolio }\end{array}$ & $\begin{array}{c}\text { Event } \\
\text { Return }\end{array}$ & $\begin{array}{c}\text { Annual } \\
\text { Return }\end{array}$ & $\begin{array}{c}\text { Ratio } \\
(\%)\end{array}$ & $\begin{array}{c}\text { Event } \\
\text { Return }\end{array}$ & $\begin{array}{c}\text { Annual } \\
\text { Return }\end{array}$ & $\begin{array}{c}\text { Ratio } \\
(\%)\end{array}$ & $\begin{array}{c}\text { Event } \\
\text { Return }\end{array}$ & $\begin{array}{c}\text { Annual } \\
\text { Return }\end{array}$ \\
\hline Year 1 & $0.792^{* *}$ & $3.330^{* *}$ & 23.78 & $1.099^{* *}$ & $5.008^{* *}$ & 21.95 & -0.079 & -1.141 \\
\hline Year 2 & $0.542^{* *}$ & $3.450^{* *}$ & 15.71 & $0.856^{*}$ & $5.192^{* *}$ & 16.49 & -0.295 & -1.194 \\
\hline Year 3 & $0.460^{* *}$ & $3.225^{* *}$ & 14.26 & $0.834^{* *}$ & $5.179 * *$ & 16.10 & -0.475 & -1.660 \\
\hline Year 4 & 0.358 & $3.056^{* *}$ & 11.72 & $0.808^{* *}$ & $4.991^{* *}$ & 16.19 & -0.693 & -1.461 \\
\hline Year 5 & 0.334 & $2.671^{* *}$ & 12.50 & $0.769 * *$ & $4.622^{* *}$ & 16.64 & -0.608 & -1.556 \\
\hline
\end{tabular}


TABLE 4

Mean Excess Returns and Regression Results for the Portfolios Formed on Cash Flow (CF) and Capital Investment (CI)

This table presents mean excess returns (Mean Return) and intercept estimates (FF alpha) from the following regression model:

$$
R_{p, t}=\alpha_{p}+\beta_{H M L, p} R_{H M L, t}+\beta_{S M B, p} R_{S M B, t}+\beta_{M k t, p}\left(R_{M k t, t}-R_{f t}\right)+\beta_{\mathrm{Pr} 1 y r, p} R_{\mathrm{Pr} 1 y r, t}+\varepsilon_{p, t}
$$

The dependent variable $\mathrm{R}_{\mathrm{p}, \mathrm{t}}$ is the excess return on a given CF/CI portfolio $\mathrm{p}$ in month $\mathrm{t}$ (described below). Refer to Table 2 for the descriptions of $\mathrm{R}_{\mathrm{ft}}, \mathrm{R}_{\mathrm{HML}, \mathrm{t}}, \mathrm{R}_{\mathrm{SMB}, \mathrm{t}}, \mathrm{R}_{\mathrm{Mk}, \mathrm{t}}$ $\mathrm{R}_{\mathrm{Prl} y \mathrm{y}}$, All Years, Non-takeover Years, Takeover Years, and Difference. Returns are in the percentage form.

The $\mathrm{CF} / \mathrm{CI}$ portfolios are formed as follows. At each June of year $\mathrm{t}$, all stocks are assigned to two groups according to their $\mathrm{CF}$ values in year $\mathrm{t}-1$. CF is measured as operating income before depreciation minus interest expenses, taxes, preferred dividends, and common dividends, and is scaled by total assets. If a firm's CF is above the median CF of the year, it is placed to the high CF group, otherwise to the low CF group. Within each CF group, stocks are sorted into quintiles based on their rankings in CI measure in ascending order. Value-weighted excess returns on a portfolio are calculated from July of year $t$ to June of year $t+1$. H-L CF CI-spread is the difference in CI-spreads between the high and low CF groups, where the CI-spread is constructed in the same way as described in Table 1. All portfolios are rebalanced each year.

The medians of the excess return series and the FF alpha series for the CI-spreads are reported in square brackets [ ]. The FF alpha series is defined by adding back the residuals to the estimated intercept. The nonparametric Wilcoxon Z-statistics for the test of medians to be equal across the two sub-periods are reported in braces \{\} . The F-values of the Wilks' Lambda statistic for the test of means to be equal across portfolios are reported in the last three rows with p-values in parentheses. * and ** represent significant at the 0.10 and 0.05 levels, respectively.

\begin{tabular}{|c|c|c|c|c|c|c|c|c|c|}
\hline \multicolumn{2}{|c|}{ Portfolio } & \multicolumn{2}{|c|}{ All Years } & \multicolumn{2}{|c|}{ Non-takeover Years } & \multicolumn{2}{|c|}{ Takeover Years } & \multicolumn{2}{|c|}{ Difference } \\
\hline $\mathrm{CI}$ & $\mathrm{CF}$ & Mean Return & FF alpha & Mean Return & FF alpha & Mean Return & FF alpha & Mean Return & FF alpha \\
\hline \multirow[t]{2}{*}{ Lowest } & Low & $-0.174^{*}$ & $-0.240^{* *}$ & -0.069 & -0.155 & $-0.472 * *$ & $-0.380 * *$ & $0.403 * *$ & 0.226 \\
\hline & High & $0.134 *$ & 0.074 & $0.188 * *$ & 0.084 & -0.020 & -0.026 & 0.209 & 0.110 \\
\hline \multirow[t]{2}{*}{2} & Low & 0.088 & 0.066 & $0.138 *$ & $0.144 *$ & -0.054 & -0.026 & 0.192 & 0.170 \\
\hline & High & $0.099 *$ & $0.156 * *$ & $0.126^{*}$ & $0.198 * *$ & 0.026 & 0.025 & 0.100 & $0.173 *$ \\
\hline \multirow[t]{2}{*}{3} & Low & 0.003 & 0.003 & 0.001 & 0.009 & 0.009 & -0.018 & -0.008 & 0.027 \\
\hline & High & 0.064 & $0.075^{*}$ & 0.065 & 0.076 & 0.064 & 0.051 & 0.001 & 0.025 \\
\hline \multirow[t]{2}{*}{4} & Low & $-0.097 *$ & -0.094 & -0.059 & -0.061 & $-0.204 * *$ & $-0.230 * *$ & 0.145 & 0.170 \\
\hline & High & -0.046 & $-0.086^{*}$ & $-0.125^{*}$ & $-0.185 * *$ & $0.179 * *$ & $0.188 * *$ & $-0.305 * *$ & $-0.373 * *$ \\
\hline \multirow[t]{2}{*}{ Highest } & Low & $-0.144 *$ & $-0.198 * *$ & $-0.204 *$ & $-0.279 * *$ & 0.024 & -0.069 & -0.228 & -0.210 \\
\hline & High & $-0.175 * *$ & $-0.195 * *$ & $-0.236 * *$ & $-0.269 * *$ & 0.000 & 0.042 & -0.236 & $-0.311 *$ \\
\hline \multirow[t]{4}{*}{ CI-spread } & Low & 0.078 & 0.059 & $0.166^{*}$ & $0.164^{*}$ & -0.173 & -0.054 & $0.339^{* *}$ & 0.218 \\
\hline & & {$[0.005]$} & {$[0.052]$} & {$[0.150]$} & {$[0.185 *]$} & {$[-0.200]$} & {$[-0.109]$} & $\left\{-1.796^{*}\right\}$ & $\{-1.383\}$ \\
\hline & High & $0.227 * *$ & $0.256^{* *}$ & $0.338 * *$ & $0.368 * *$ & -0.087 & -0.115 & $0.425 * *$ & $0.483 * *$ \\
\hline & & {$[0.268 * *]$} & {$[0.301 * *]$} & {$[0.405 * *]$} & {$[0.482 * *]$} & {$[0.021]$} & {$[0.063]$} & $\{-2.770 * *\}$ & $\{-3.078 * *\}$ \\
\hline \multirow{2}{*}{\multicolumn{2}{|c|}{ H-L CF CI-spread }} & 0.149 & $0.197^{*}$ & 0.172 & $0.204^{*}$ & 0.086 & -0.061 & 0.086 & 0.265 \\
\hline & & {$[0.210]$} & {$[0.227 * *]$} & {$[0.281]$} & {$[0.234 *]$} & {$[-0.032]$} & {$[-0.030]$} & $\{-0.684\}$ & $\{-1.340\}$ \\
\hline \multirow{5}{*}{$\begin{array}{l}\text { Wilks' } \\
\text { Lambda }\end{array}$} & Low & 2.11 & 2.57 & 1.55 & 2.29 & 2.03 & 1.30 & & \\
\hline & (p-value) & $(0.080)$ & $(0.038)$ & $(0.190)$ & $(0.061)$ & $(0.100)$ & $(0.280)$ & & \\
\hline & $\begin{array}{c}\text { High } \\
\text { (p-value) }\end{array}$ & $\begin{array}{c}2.50 \\
(0.043) \\
\end{array}$ & $\begin{array}{c}3.48 \\
(0.009)\end{array}$ & $\begin{array}{c}3.64 \\
(0.007)\end{array}$ & $\begin{array}{c}4.96 \\
(0.001)\end{array}$ & $\begin{array}{c}0.82 \\
(0.514)\end{array}$ & $\begin{array}{c}0.73 \\
(0.573)\end{array}$ & & \\
\hline & CI-spread & 2.16 & 3.57 & 2.00 & 2.73 & 0.22 & 0.11 & & \\
\hline & across CF & $(0.143)$ & $(0.060)$ & $(0.159)$ & $(0.100)$ & $(0.639)$ & $(0.745)$ & & \\
\hline
\end{tabular}


TABLE 5

Mean Excess Returns and Regression Results for the Portfolios Formed on Debt-to-Assets Ratio (DA) and Capital Investment (CI)

This table presents mean excess returns (Mean Return) and intercept estimates (FF alpha) from the following regression model:

$$
R_{p, t}=\alpha_{p}+\beta_{H M L, p} R_{H M L, t}+\beta_{S M B, p} R_{S M B, t}+\beta_{M k t, p}\left(R_{M k t, t}-R_{f t}\right)+\beta_{\mathrm{Pr} 1 y r, p} R_{\mathrm{Pr} 1 y r, t}+\varepsilon_{p, t}
$$

The dependent variable $\mathrm{R}_{\mathrm{p}, \mathrm{t}}$ is the excess return on a given DA/CI portfolio $\mathrm{p}$ in month $\mathrm{t}$ (described below). Refer to Table 2 for descriptions of $\mathrm{R}_{\mathrm{ft}}, \mathrm{R}_{\mathrm{HML}, \mathrm{t}}, \mathrm{R}_{\mathrm{SMB}, \mathrm{t}}, \mathrm{R}_{\mathrm{Mk}, \mathrm{t}}$ $\mathrm{R}_{\mathrm{Prly}}$, All Years, Non-takeover Years, Takeover Years, and Difference. Returns are in the percentage form.

The DA/CI portfolios are formed as follows. At each June of year $t$, all stocks are assigned to two groups according to their values in debt-to-assets ratio DA in year $\mathrm{t}-1$. DA is defined as the ratio of long-term debt over the sum of long-term debt and the market value of firm's equity. If a firm's DA is above the median DA of the year, it is designated to the high debt group, otherwise to the low debt group. Within each DA group, stocks are sorted into quintiles based on their rankings in CI measure in ascending order. Value-weighted excess returns on a portfolio are calculated from July of year $t$ to June of year $t+1$. H-L DA CI-spread is the difference in the CI-spread between the high and low DA groups, where the CI-spread is constructed in the same way as described in Table 1. All portfolios are rebalanced each year.

The medians of the excess return series and the FF alpha series for the CI-spreads are reported in square brackets [ ]. The FF alpha series is defined by adding back the residuals to the estimated intercept. The nonparametric Wilcoxon Z-statistics for the test of medians to be equal across the two sub-periods are reported in braces \{\} . The F-values of the Wilks' Lambda statistic for the test of means to be equal across portfolios are reported in the last three rows with p-values in parentheses. * and ** represent significant at the 0.10 and 0.05 levels, respectively.

\begin{tabular}{|c|c|c|c|c|c|c|c|c|c|}
\hline \multicolumn{2}{|c|}{ Portfolio } & \multicolumn{2}{|c|}{ All Years } & \multicolumn{2}{|c|}{ Non-takeover Years } & \multicolumn{2}{|c|}{ Takeover Years } & \multicolumn{2}{|c|}{ Difference } \\
\hline $\mathrm{CI}$ & DA & Mean Return & FF alpha & Mean Return & FF alpha & Mean Return & FF alpha & Mean Return & FF alpha \\
\hline \multirow[t]{2}{*}{ Lowest } & Low & $0.133^{*}$ & $0.146^{*}$ & $0.238^{* *}$ & $0.240 * *$ & -0.165 & -0.074 & $0.403^{* *}$ & $0.314 * *$ \\
\hline & High & 0.034 & -0.071 & 0.135 & 0.010 & -0.253 & -0.279 & $0.388 * *$ & 0.289 \\
\hline \multirow[t]{2}{*}{2} & Low & 0.060 & $0.116^{* *}$ & 0.071 & $0.148 * *$ & 0.029 & -0.021 & 0.041 & $0.169 *$ \\
\hline & High & 0.078 & 0.025 & 0.117 & 0.052 & -0.031 & 0.029 & 0.148 & 0.022 \\
\hline \multirow[t]{2}{*}{3} & Low & 0.048 & 0.032 & 0.054 & 0.025 & 0.031 & 0.055 & 0.023 & -0.030 \\
\hline & High & 0.062 & $0.092 *$ & 0.099 & $0.140 * *$ & -0.042 & -0.053 & 0.142 & $0.193 *$ \\
\hline \multirow[t]{2}{*}{4} & Low & $-0.090 *$ & $-0.103 * *$ & $-0.123 * *$ & $-0.146^{* *}$ & 0.005 & -0.007 & -0.129 & -0.319 \\
\hline & High & -0.063 & $-0.115^{*}$ & -0.093 & $-0.160 * *$ & 0.020 & -0.006 & -0.112 & -0.154 \\
\hline \multirow[t]{2}{*}{ Highest } & Low & $-0.167 *$ & $-0.206 * *$ & $-0.235 * *$ & $-0.300 * *$ & 0.024 & 0.019 & -0.259 & $-0.319 *$ \\
\hline & High & -0.023 & -0.092 & -0.074 & $-0.152 *$ & 0.120 & 0.100 & -0.193 & -0.252 \\
\hline \multirow[t]{4}{*}{ CI-spread } & Low & $0.225 * *$ & $0.286 * *$ & $0.334 * *$ & $0.417 * *$ & -0.082 & -0.054 & $0.416^{* *}$ & $0.471^{* *}$ \\
\hline & & {$[0.157 * *]$} & {$[0.243 * *]$} & {$[0.300 * *]$} & {$[0.394 * *]$} & {$[0.035]$} & {$[0.059]$} & $\{-2.563 * *\}$ & $\{-3.157 * *\}$ \\
\hline & High & 0.099 & 0.080 & $0.209 * *$ & $0.187 * *$ & -0.212 & -0.172 & $0.421 * *$ & $0.359 * *$ \\
\hline & & [0.012] & {$[-0.025]$} & {$[0.257 * *]$} & {$[0.253 * *]$} & {$[-0.192 *]$} & {$\left[-0.165^{*}\right]$} & $\{-2.660 * *\}$ & $\{-2.338 * *\}$ \\
\hline \multirow{2}{*}{\multicolumn{2}{|c|}{ H-L DA CI-spread }} & -0.126 & $-0.206^{*}$ & -0.124 & $-0.231 *$ & -0.129 & -0.118 & 0.005 & -0.112 \\
\hline & & {$[-0.240]$} & {$[-0.270 * *]$} & {$[-0.210]$} & {$[-0.308 *]$} & {$[-0.272]$} & {$[-0.266]$} & $\{0.011\}$ & $\{0.379\}$ \\
\hline \multirow{5}{*}{$\begin{array}{l}\text { Wilks' } \\
\text { Lambda }\end{array}$} & Low & 2.29 & 3.43 & 3.38 & 4.90 & 0.61 & 0.23 & & \\
\hline & (p-value) & $(0.060)$ & $(0.009)$ & $(0.011)$ & $(0.001)$ & $(0.654)$ & $(0.922)$ & & \\
\hline & $\begin{array}{c}\text { High } \\
\text { (p-value) }\end{array}$ & $\begin{array}{c}0.95 \\
(0.434)\end{array}$ & $\begin{array}{c}2.15 \\
(0.075)\end{array}$ & $\begin{array}{c}1.92 \\
(0.109)\end{array}$ & $\begin{array}{c}3.20 \\
(0.014)\end{array}$ & $\begin{array}{c}0.71 \\
(0.585)\end{array}$ & $\begin{array}{c}0.73 \\
(0.578)\end{array}$ & & \\
\hline & CI-spread & 1.37 & 3.53 & 0.90 & 2.98 & 0.52 & 0.36 & & \\
\hline & across DA & $(0.242)$ & $(0.062)$ & $(0.343)$ & $(0.086)$ & $(0.472)$ & $(0.551)$ & & \\
\hline
\end{tabular}


TABLE 6

Fama-MacBeth Regression Results

This table reports the Fama-MacBeth regression results for the following models:

$$
\begin{aligned}
& \text { Model 1: } R_{i t}=\lambda_{0, t}+\lambda_{1, t} C I_{i, t-1}+\lambda_{2, t} C I_{i, t-1} \times D C F_{i, t-1}+\varepsilon_{i, t}, \quad t=1, \ldots, T, \\
& \text { Model 2: } R_{i t}=\lambda_{0, t}+\lambda_{1, t} C I_{i, t-1}+\lambda_{3, t} C I_{i, t-1} \times D D A_{i, t-1}+\varepsilon_{i, t}, \quad t=1, \ldots, T, \\
& \text { Model 3: } R_{i t}=\lambda_{0, t}+\lambda_{1, t} C I_{i, t-1}+\lambda_{2, t} C I_{i, t-1} \times D C F_{i, t-1}+\lambda_{3, t} C I_{i, t-1} \times D D A_{i, t-1}+\varepsilon_{i, t}, \quad t=1, \ldots, T,
\end{aligned}
$$

where $R_{i, t}$ is the benchmark-adjusted value-weighted return on individual stock $i$ at time $t$. It is weighted by the firm's market value relative to the total market value for a given CI rank in a given year multiplied by 1,000 . CI is the capital investment measure. $D C F$ and $D D A$ are the dummy variables based on cash flow (CF) and debt to assets ratio (DA), respectively. $\mathrm{CF}$ is measured as operating income before depreciation minus interest expenses, taxes, preferred dividends, and common dividends, and is scaled by total assets. If a firm's CF is above the median CF of the year, $D C F$ equals one, otherwise $D C F$ equals zero. DA is defined as the ratio of long-term debt over the sum of long-term debt and the market value of firm's equity. If a firm's DA is above the median DA of the year, then $D D A$ equals one, otherwise $D D A$ equals zero. To reduce the inference from extreme outliers, the bottom and top $1.5 \%$ of the observations (based on adjusted return variable) are excluded from the sample.

Panel A reports the regression results for all years, Panel B for non-takeover years, and Panel C for takeover years. All years refer to the whole sample period (July 1973 to June 1996). Takeover years refer to the period of time from 1984

\begin{tabular}{|c|c|c|c|c|}
\hline & Intercept & $\lambda_{1}$ & $\lambda_{2}$ & $\lambda_{3}$ \\
\hline \multicolumn{5}{|c|}{ Panel A: All Years } \\
\hline Model (1) & $\begin{array}{c}0.03 \\
(0.50)\end{array}$ & $\begin{array}{l}-0.79 * * \\
(-2.80)\end{array}$ & $\begin{array}{l}-0.76^{* *} \\
(-2.19)\end{array}$ & \\
\hline Model (2) & $\begin{array}{c}0.40 \\
(0.71)\end{array}$ & $\begin{array}{l}-0.61 * * \\
(-2.16)\end{array}$ & & $\begin{array}{c}0.49 * \\
(1.64)\end{array}$ \\
\hline Model (3) & $\begin{array}{c}0.40 \\
(0.77)\end{array}$ & $\begin{array}{c}-0.95 * * \\
(-2.76)\end{array}$ & $\begin{array}{l}-0.73 * * \\
(-2.04)\end{array}$ & $\begin{array}{c}0.38 \\
(1.25)\end{array}$ \\
\hline \multicolumn{5}{|c|}{ Panel B: Non-takeover Years } \\
\hline Model (1) & $\begin{array}{c}0.60 \\
(0.96)\end{array}$ & $\begin{array}{l}-1.06^{* *} \\
(-2.96)\end{array}$ & $\begin{array}{l}-0.85 * * \\
(-1.92)\end{array}$ & \\
\hline Model (2) & $\begin{array}{c}0.70 \\
(1.16)\end{array}$ & $\begin{array}{l}-0.87 * * \\
(-2.40)\end{array}$ & & $\begin{array}{c}0.56 \\
(1.51)\end{array}$ \\
\hline Model (3) & $\begin{array}{c}0.70 \\
(1.18)\end{array}$ & $\begin{array}{l}-1.25 * * \\
(-2.85)\end{array}$ & $\begin{array}{c}-0.81 * \\
(-1.79)\end{array}$ & $\begin{array}{c}0.46 \\
(1.20)\end{array}$ \\
\hline \multicolumn{5}{|c|}{ Panel C: Takeover Years } \\
\hline Model (1) & $\begin{array}{c}-0.08 \\
(-1.35)\end{array}$ & $\begin{array}{c}-0.02 \\
(-0.06)\end{array}$ & $\begin{array}{c}-0.53 \\
(-1.13)\end{array}$ & \\
\hline Model (2) & $\begin{array}{c}-0.07 \\
(-1.23)\end{array}$ & $\begin{array}{c}0.13 \\
(0.41)\end{array}$ & & $\begin{array}{c}0.28 \\
(0.62)\end{array}$ \\
\hline Model (3) & $\begin{array}{c}-0.07 \\
(-1.10)\end{array}$ & $\begin{array}{c}-0.07 \\
(-0.18)\end{array}$ & $\begin{array}{c}-0.49 \\
(-1.03)\end{array}$ & $\begin{array}{c}0.17 \\
(0.37)\end{array}$ \\
\hline
\end{tabular}
to 1989 . Non-takeover years refer to the period that excludes the takeover years. $\mathrm{t}$-values are in parenthesis. $*$ and $* *$ represent significant at the 0.10 and 0.05 levels, respectively. 
TABLE 7

The Capital Investment Effect versus the Contrarian Effect

At end of each June from 1973 to 1996, all firms are sorted into PR quintiles from smallest to largest based on their past five-year returns (denoted as PR) at the end of June of year $t$. Firms are also sorted into CI quintiles from lowest to highest based on their CI measures at the end of year $t-1$. The 25 portfolios are constructed from the intersections of the five PR groups and the five CI groups. Monthly value-weighted excess returns for each of these 25 portfolios are calculated from July of year $t$ to June of year $t$-1. The PR-spread is constructed in the same way as for the CI-spread described in Table 1 . Average CI-spread (PR-spread) is the average of the five CI-spreads (PR-spreads). All portfolios are rebalanced each year.

All years refer to the whole sample period (July 1973 to June 1996). Takeover years refer to the period of time from 1984 to 1989 . Non-takeover years refer to the period that excludes the takeover years. Returns are in the percentage form. $*$ and $* *$ represent significant at the 0.10 and 0.05 levels, respectively.

Panel A: Benchmark-adjusted returns, all years (1973-1996)

\begin{tabular}{|c|c|c|c|c|c|c|}
\hline \hline Past 5-year & \multicolumn{7}{|c|}{ CI measures at the end of year t-1 } \\
\cline { 2 - 7 } returns & Lowest & 2 & 3 & 4 & Highest & CI-spread \\
\hline \hline Smallest & 0.310 & 0.146 & 0.166 & -0.175 & -0.002 & 0.317 \\
2 & 0.285 & -0.000 & 0.163 & -0.055 & -0.066 & 0.202 \\
3 & -0.032 & 0.089 & 0.072 & -0.009 & -0.360 & 0.213 \\
4 & 0.122 & 0.097 & 0.108 & 0.064 & 0.065 & 0.013 \\
Largest & 0.075 & -0.087 & 0.189 & -0.253 & $-0.322^{*}$ & $0.281^{*}$ \\
\hline PR-spread & 0.068 & 0.068 & 0.016 & -0.020 & 0.094 & \\
\hline Average CI-spread =0.159** \\
Average PR-spread $=0.093$
\end{tabular}

Panel B: Benchmark-adjusted returns, non-takeover years (1984 - 1989 excluded)

\begin{tabular}{|c|c|c|c|c|c|c|}
\hline \hline \multirow{2}{*}{$\begin{array}{c}\text { Past 5-year } \\
\text { returns }\end{array}$} & Lowest & 2 & 3 & 4 & Highest & CI-spread \\
\cline { 2 - 7 } & 0.466 & 0.279 & 0.258 & -0.207 & -0.023 & 0.487 \\
Smallest & 0.424 & 0.036 & 0.122 & -0.023 & -0.053 & 0.268 \\
2 & 0.005 & 0.055 & 0.109 & -0.017 & -0.482 & 0.279 \\
3 & 0.239 & 0.165 & 0.168 & -0.004 & -0.022 & 0.178 \\
4 & 0.217 & -0.052 & 0.219 & -0.302 & -0.534 & $0.501^{* *}$ \\
Largest & 0.041 & 0.101 & -0.004 & 0.038 & 0.240 & \\
\hline PR-spread & \multicolumn{5}{|c}{} \\
\hline Average CI-spread = $0.285^{* *}$ \\
Average PR-spread =0.152
\end{tabular}

Panel C: Benchmark-adjusted returns, takeover years (1984-1989)

\begin{tabular}{|c|c|c|c|c|r|c|}
\hline \hline \multirow{2}{*}{$\begin{array}{c}\text { Past 5-year } \\
\text { returns }\end{array}$} & Lowest & 2 & 3 & 4 & Highest & CI-spread \\
\cline { 2 - 7 } & -0.131 & -0.229 & -0.095 & -0.084 & 0.058 & -0.167 \\
Smallest & -0.109 & -0.105 & 0.279 & -0.144 & -0.104 & 0.017 \\
2 & -0.138 & 0.187 & -0.026 & 0.013 & -0.012 & 0.024 \\
3 & -0.190 & -0.098 & -0.062 & 0.254 & 0.314 & $-0.428^{* *}$ \\
4 & -0.329 & -0.187 & 0.102 & -0.115 & 0.281 & $-0.341^{*}$ \\
Largest & 0.139 & -0.024 & 0.072 & -0.184 & -0.321 & \\
\hline PR-spread & \multicolumn{5}{|c|}{} \\
\hline Average CI-spread = -0.179 \\
Average PR-spread = -0.063
\end{tabular}


TABLE 8

Mean Excess Returns and Regression Results for the CI Portfolios Excluding IPO/SEO Firms

This table reports the mean excess returns (Mean Return) and the intercept estimates (FF alpha) from the following regression model:

$$
R_{p, t}=\alpha_{p}+\beta_{H M L, p} R_{H M L, t}+\beta_{S M B, p} R_{S M B, t}+\beta_{M k t, p}\left(R_{M k t, t}-R_{f t}\right)+\beta_{\operatorname{Pr} 1 y r, p} R_{\operatorname{Pr} 1 y r, t}+\varepsilon_{p, t}
$$

The dependent variable $\mathrm{R}_{\mathrm{p}, \mathrm{t}}$ is the excess return on a given CI portfolio $\mathrm{p}$ in month t. Only firms that have not raised new equity in the past five years after a new issue are included in the sample. The five CI portfolios are formed based on their CI measures in year t-1and rebalanced each year. Refer to Table 2 for the descriptions of $\mathrm{R}_{\mathrm{ft}}$, $\mathrm{R}_{\mathrm{HML}, \mathrm{t}}, \mathrm{R}_{\mathrm{SMB}, \mathrm{t}}, \mathrm{R}_{\mathrm{Mkt}, \mathrm{t}}, \mathrm{R}_{\mathrm{Prly}}$, All Years, Non-takeover Years, Takeover Years, and Difference. Returns are in percentage form.

The medians of the excess return series and the FF alpha series are reported in square brackets [ ]. The FF alpha series is defined by adding back the residuals to the estimated intercept. The nonparametric Wilcoxon Z-statistics for the test of medians to be equal across the two sub-periods are reported in braces \{\} . The F-values of the Wilks' Lambda statistic for the test of means to be equal and the Chi-square values of the nonparametric Kruskal-Wallis test for the test of medians to be equal across the five CI portfolios are reported in the last two rows with p-values in parentheses. * and ** represent significant at the 0.10 and 0.05 levels, respectively.

\begin{tabular}{|c|c|c|c|c|c|c|c|c|}
\hline Portfolio & \multicolumn{2}{|c|}{ All Years } & \multicolumn{2}{|c|}{ Non-takeover Years } & \multicolumn{2}{|c|}{ Takeover Years } & \multicolumn{2}{|c|}{ Difference } \\
\hline CI & Mean Return & FF alpha & Mean Return & FF alpha & Mean Return & FF alpha & Mean Return & FF alpha \\
\hline Lowest & $\begin{array}{c}0.094 \\
{[0.123]}\end{array}$ & $\begin{array}{c}0.028 \\
{[0.009]}\end{array}$ & $\begin{array}{c}0.184 * * \\
{[0.240 * *]}\end{array}$ & $\begin{array}{c}0.103 \\
{[0.097]}\end{array}$ & $\begin{array}{c}-0.162 \\
{[-0.258]}\end{array}$ & $\begin{array}{c}-0.187 \\
{[-0.287]}\end{array}$ & $\begin{array}{c}0.347 * * \\
\{-2.320 * *\}\end{array}$ & $\begin{array}{r}0.290^{* *} \\
\{-2.048\}\end{array}$ \\
\hline 2 & $\begin{array}{c}0.083^{*} \\
{\left[0.114^{* *}\right]}\end{array}$ & $\begin{array}{c}0.124 * * \\
{\left[0.119^{* *}\right]}\end{array}$ & $\begin{array}{c}0.108 * * \\
{[0.162 * *]}\end{array}$ & $\begin{array}{c}0.163^{* *} \\
{\left[0.153^{* *}\right]}\end{array}$ & $\begin{array}{c}0.013 \\
{[0.012]}\end{array}$ & $\begin{array}{c}0.055 \\
{[0.108]}\end{array}$ & $\begin{array}{c}0.094 \\
\{-0.787\}\end{array}$ & $\begin{array}{c}0.108 \\
\{-0.918\}\end{array}$ \\
\hline 3 & $\begin{array}{c}0.083 * * \\
{[0.081 * *]}\end{array}$ & $\begin{array}{c}0.076^{*} \\
{\left[0.078^{* *}\right]}\end{array}$ & $\begin{array}{c}0.117 * * \\
{[0.108 * *]}\end{array}$ & $\begin{array}{c}0.107 * * \\
{[0.109 * *]}\end{array}$ & $\begin{array}{l}-0.014 \\
{[0.007]}\end{array}$ & $\begin{array}{l}-0.034 \\
{[0.028]}\end{array}$ & $\begin{array}{r}0.131 * \\
\{-1.552\}\end{array}$ & $\begin{array}{c}0.142^{*} \\
\left\{-1.790^{*}\right\}\end{array}$ \\
\hline 4 & $\begin{array}{c}-0.072 * * \\
{[-0.084 * *]}\end{array}$ & $\begin{array}{c}-0.103 * * \\
{[-0.084 * *]}\end{array}$ & $\begin{array}{c}-0.131^{* *} \\
{\left[-0.121^{* *}\right]}\end{array}$ & {$\left[-0.177^{* *}\right.$} & $\begin{array}{c}0.095 \\
{[0.061]}\end{array}$ & $\begin{array}{c}0.089 \\
{[0.066]}\end{array}$ & $\begin{array}{l}-0.226^{* *} \\
\left\{2.826^{* *}\right\}\end{array}$ & $\begin{array}{l}-0.266^{* *} \\
\left\{3.336^{* *}\right\}\end{array}$ \\
\hline Highest & $\begin{array}{c}-0.123^{*} \\
{[-0.056]}\end{array}$ & $\begin{array}{c}-0.161 * * \\
{[-0.143 * *]}\end{array}$ & $\begin{array}{c}-0.174 * * \\
{[-0.116 * *]}\end{array}$ & $\begin{array}{c}-0.228 * * \\
{[-0.199 * *]}\end{array}$ & $\begin{array}{c}0.023 \\
{[0.138]}\end{array}$ & $\begin{array}{c}0.031 \\
{[0.100]}\end{array}$ & $\begin{array}{l}-0.198 \\
\{1.588\}\end{array}$ & $\begin{array}{l}-0.266^{* *} \\
\left\{1.951^{*}\right\}\end{array}$ \\
\hline CI-spread & $\begin{array}{c}0.186^{* *} \\
{\left[0.146^{* *}\right]}\end{array}$ & $\begin{array}{c}0.208^{* *} \\
{[0.165 * *]}\end{array}$ & $\begin{array}{c}0.299 * * \\
{[0.347 * *]}\end{array}$ & $\begin{array}{c}0.336^{* *} \\
{\left[0.413^{* *}\right]}\end{array}$ & $\begin{array}{c}-0.133 \\
{[-0.197 *]}\end{array}$ & $\begin{array}{l}-0.126 \\
{\left[-0.210^{*}\right]}\end{array}$ & $\begin{array}{c}0.432 * * \\
\{-3.832 * *\}\end{array}$ & $\begin{array}{c}0.461^{* *} \\
\left\{-4.190^{* *}\right\}\end{array}$ \\
\hline $\begin{array}{l}\text { Wilks' Lambda } \\
\text { (p-value) }\end{array}$ & $\begin{array}{l}2.97 \\
(0.020)\end{array}$ & $\begin{array}{l}4.52 \\
(0.001)\end{array}$ & $\begin{array}{l}5.12 \\
(0.001)\end{array}$ & $\begin{array}{l}6.99 \\
(0.000)\end{array}$ & $\begin{array}{l}0.99 \\
(0.419)\end{array}$ & $\begin{array}{l}1.08 \\
(0.375)\end{array}$ & & \\
\hline $\begin{array}{l}\text { Kruskal-Wallis test } \\
\text { (p-value) }\end{array}$ & $\begin{array}{l}15.53 \\
(0.003)\end{array}$ & $\begin{array}{c}25.72 \\
(<0.001)\end{array}$ & $\begin{array}{c}28.24 \\
(<0.001)\end{array}$ & $\begin{array}{c}39.28 \\
(<0.001)\end{array}$ & $\begin{array}{l}4.66 \\
(0.323)\end{array}$ & $\begin{array}{l}7.38 \\
(0.117)\end{array}$ & & \\
\hline
\end{tabular}

